\title{
Public acceptance of renewable energies and energy autonomy: A comparative study in the French, German and Swiss Upper Rhine region
}

Schumacher, Kim; Krones, F.; McKenna, Russell; Schultmann, F.

Published in:

Energy Policy

Link to article, DOI:

10.1016/j.enpol.2018.11.032

Publication date:

2019

Document Version

Peer reviewed version

Link back to DTU Orbit

Citation (APA):

Schumacher, K., Krones, F., McKenna, R., \& Schultmann, F. (2019). Public acceptance of renewable energies and energy autonomy: A comparative study in the French, German and Swiss Upper Rhine region. Energy Policy, 126, 315-332. https://doi.org/10.1016/j.enpol.2018.11.032

\section{General rights}

Copyright and moral rights for the publications made accessible in the public portal are retained by the authors and/or other copyright owners and it is a condition of accessing publications that users recognise and abide by the legal requirements associated with these rights.

- Users may download and print one copy of any publication from the public portal for the purpose of private study or research.

- You may not further distribute the material or use it for any profit-making activity or commercial gain

- You may freely distribute the URL identifying the publication in the public portal 
See discussions, stats, and author profiles for this publication at: https://www.researchgate.net/publication/329239323

Public acceptance of renewable energies and energy autonomy: A comparative study in the French, German and Swiss Upper Rhine region

Article in Energy Policy · November 2018

DOI: 10.1016/j.enpol.2018.11.032

\section{CITATIONS}

17

4 authors:

Kira Schumacher

Karlsruhe Institute of Technology

5 PUBlications 32 Citations

SEE PROFILE

Russell Mckenna

University of Aberdeen

101 PUBLICATIONS 1,162 CITATIONS

SEE PROFILE
READS

657

3. Felix Krones

ETH Zurich

1 PUBLICATION 17 CITATIONS

SEE PROFILE

Frank Schultmann

Karlsruhe Institute of Technology

149 PUBlications 2,547 CITATIONS

SEE PROFILE

Some of the authors of this publication are also working on these related projects:

Project Innovations for sustainable biomass utlisation in the Upper Rhine region View project

Project Bidirectional Charging Management (BDL) View project 


\title{
PUBLIC ACCEPTANCE OF RENEWABLE ENERGIES AND ENERGY \\ AUTONOMY: A COMPARATIVE STUDY IN THE FRENCH, GERMAN \\ AND SWISS UPPER RHINE REGION
}

\author{
K. SCHUMACHER ${ }^{1 *}$, F. KRONES ${ }^{1}$, R. MCKENNA² and F. SCHULTMANN ${ }^{1}$ \\ ${ }^{1}$ Chair of Business Administration, Production and Operations Management, Karlsruhe \\ Institute of Technology (KIT), Hertzstraße 16, 76187 Karlsruhe, Germany \\ ${ }^{2}$ Chair of Energy Economics, Karlsruhe Institute for Technology (KIT), Hertzstraße 16, \\ 76187 Karlsruhe, Germany
}

*Corresponding author: kira.schumacher@kit.edu, + 49721608 44572,+49 72160844682

\begin{abstract}
In the context of climate change mitigation and increasing decentralized generation of energy from renewable sources, public acceptance of renewable energy (RE) has become an important issue in energy research. Many studies have addressed public acceptance through a case-based empirical lens with rather specific conclusions for individual technologies in a given context. This paper draws more universal insights by conducting an online survey on public acceptance for a set of technologies in the three sub-regions of the Upper Rhine region (URR). Using a representative dataset of 495 German, 501 French, and 493 Swiss inhabitants of the URR, several hypotheses from the acceptance literature are tested across sub-regions and RE technologies and results are compared to related empirical studies from the literature. Moreover, we explore for the first time how public acceptance is linked with community energy and energy autonomy. The latter is especially important to understand how policy and project initiators can mobilise the population to contribute to the energy transition. Our main
\end{abstract}


findings are that public acceptance is, inter alia, highly dependent on the technology in question, the dimension of social acceptance (community versus socio-political dimension) and previous experiences with RE technologies.

Keywords: Public acceptance; Renewable energy; International survey; Energy autonomy; Community energy. 


\section{INTRODUCTION}

In the context of the so-called energy transition, national energy systems are currently undergoing fundamental structural changes. In particular, this involves a rapid development of renewable energies (RE), from around $15 \%$ of electricity generation in 2005 to almost $30 \%$ in 2015 in Europe (European Commission, 2017). As well as economic, technical and environmental challenges, this development has a significant social dimension. Transforming existing large-scale, mainly centralized electricity systems into smaller, at least partly decentralized ones changes the geographic energy landscape (Fast, 2013; McKenna, 2018; Wolsink, 2018) and increases the number of contact points between society and plants for energy generation (Kortsch et al., 2015). On the one hand, the lack of public acceptance has been particularly manifested in protests to large-scale RE projects (Griesen, 2010). On the other hand, there are a growing number of examples of public support and engagement for REs, especially in the context of community energy. In these projects, local stakeholders are involved along the value chain and stand to reap the benefits (Walker, 2008; Walker et al., 2010). Precisely this direct engagement can be a key influencing factor for the level of public acceptance (Aitken, 2010) and is arguably equally if not more important than the technologies themselves. Some of these community energy projects have the explicit objective of becoming energy autonomous, which they typically define as generating enough electricity to meet their demand on an annual basis (Müller et al., 2011; Rae and Bradley, 2012).

So far, however, scholars have mostly focused on explaining the phenomena of nonacceptance or rejection, without a deeper analysis of the different facets of positive acceptance and support (Batel et al., 2016; for a review, see Fast, 2013). This lacking attention with regard to support risks neglecting the active engagement of the public for the transition towards RE. Moreover, existing studies predominantly examine public acceptance 
as a (static) position of a specific (or several) actor(s) towards a specific RE project within a specific country, hence, adopting a case-based point of view. Comparison between studies is often difficult because of non-representative, case-based data on the one hand, and differences in research designs (such as measurement instruments, sample characteristics, timeframes) on the other. Looking at the literature (cf. section 2), there is a distinct lack of research that takes a comparative approach by examining public acceptance of several RE technologies within different national contexts on the basis of representative data.

This paper takes this gap in the literature as the starting point for a tri-national analysis of public acceptance of a set of RE technologies in the Upper Rhine region (URR). It employs representative data for the three sub-regions of the URR, which are the territory of Alsace (France), the northwest region of Switzerland, a large part of Baden (part of BadenWürttemberg, Germany), and the south part of Rhineland-Palatinate (Germany). The objective is thereby to compare the acceptance of those technologies that, apart from hydropower, account for around $66 \%$ of renewable electricity in Europe (Agora Energiewende, 2016; REN 21, 2017): wind (37\%), solar (11\%) and bioenergy (18\%). The comparison between technologies and sub-regions enables us to test hypotheses from acceptance research with regard to their universality for different acceptance objects in different acceptance contexts. Taking a comparative, cross-regional research approach, the following six hypotheses $(\mathrm{H})$ are comparatively tested between sub-regions and $\mathrm{RE}$ technologies:

- H1: REs generally enjoy high public acceptance for future energy generation.

- H2: There is public disposition to act towards RE plants in the neighbourhood.

- H3: General public acceptance (socio-political dimension) exceeds public acceptance of plants in the neighbourhood (community dimension). 
- H4: Public acceptance of RE plants is influenced by the distance of the plant to the respondent's home.

- H5: Public acceptance of RE plants is higher among respondents with previous experience with RE projects.

- H6: Public acceptance and community energy are related to energy autonomy.

Moreover, this contribution complements existing literature by examining the link between public acceptance of REs, community energy and energy autonomy together and in different national contexts.

The remainder of this paper is structured as follows: section 2 highlights relevant theoretical concepts for the study and defines our understanding of social acceptance of REs and the scope of the study. Section 3 describes the study design by introducing the study region and the methodological approach of data collection and analysis, including the survey design, the sampling procedure, the questionnaire as well as the data processing. Section 4 presents the results of the survey along the above six hypotheses, which are tested across national subregions and RE technologies. Section 5 sums up the results and provides a comparison of our findings with the related literature. Finally, section 6 concludes with policy recommendations to increase public acceptance of REs. 


\section{STATUS QUO OF SOCIAL ACCEPTANCE RESEARCH FOR}

\section{RENEWABLE ENERGIES}

\subsection{Defining social acceptance of renewable energies and the study scope}

Due to the abstract nature of social acceptance, there are various theoretical concepts and definitions suggested by the literature. In this section we therefore present three relevant concepts from the social acceptance literature according to which we then precisely define the scope of our study. We suggest that other studies should equally report on (i) the acceptance dimension (ii) the acceptance subject, object and context as well as (iii) a definition of the term acceptance they use as basis for their studies.

(i) Acceptance dimension: Wüstenhagen et al. (2007) introduced a concept distinguishing between three dimensions of social acceptance, which are socio-political, community, and market acceptance. Whereas socio-political acceptance deals with the acceptance of institutional settings of REs by key stakeholders as well as the acceptance of REs by the larger public; community acceptance refers to specific RE plants and the reactions of the local stakeholders which are directly affected, such as residents and local authorities. Market acceptance refers to the diffusion of RE technologies within the market and the extent to which its participants, such as consumers and companies, accept them (cf. also Sovacool and Ratan, 2012; Wolsink, 2017). In each of the three dimensions different stakeholders are present and influence social acceptance of REs through their interplay. Table 1 displays the three interdependent and non-hierarchical dimensions and provides examples of stakeholders participating in each of them (cf. Wüstenhagen et al., 2007; Wolsink, 2017).

[Table 1 about here] 
(ii) Acceptance subject, object and context: According to Lucke (1995), it is further necessary to carefully define what is accepted (or not), by whom, in which society, situation, and at which point in time, due to which reasons and motives. Lucke (1995) hereby highlights the relational and transitive nature of acceptance, claiming that acceptance is highly dependent on the subject, the object, and the context of acceptance. The acceptance subject, i.e. the person, institution or company supposed to accept, may assume different roles (cf. Table 1). With regard to public acceptance, a person can evaluate RE technologies from a general point of view, e.g. as a citizen, from a specific point of view, e.g. as a resident living next to a RE plant, or from the market perspective, e.g. as a consumer. The object of acceptance, i.e. the policy, technology, infrastructure to be accepted by the acceptance subject, can range from RE projects with their specific characteristics (e.g. a community owned wind park), framework conditions for REs (e.g. subsidies, tariffs), or RE related infrastructure (e.g. high voltage power lines). The acceptance context varies according to the acceptance situation. For example, the national context is supposed to be a relevant factor, even though few studies have addressed this issue in depth so far (Sovacool, 2014).

(iii) Acceptance definition: An often cited concept by Schweizer-Ries (2008) defines the term "acceptance" in the context of REs by an attitudinal and an action-level. The definition hence differentiates between four levels of (non)-acceptance: passive acceptance, called "approval", and active acceptance, called "support", passive non-acceptance, called "rejection", and active non-acceptance, called "resistance" (cf. also Rau et al., 2012). This definition is however limited to the psychological perspective of (static) actor positions and does not account for the multiple interactions between the actors. Also the four levels of acceptance (approval, support, rejection and resistance) are a simplification as public acceptance unfolds in a dynamic process with many different positions and actions, manifesting in many different forms, such as tolerance, apathy, indifference, uncertainty etc. 
(cf. Wüstenhagen, 2007; Wolsink, 2018). Despite those limitations, the definition allows us to operationalise the abstract term "acceptance" and is therefore used in this paper to assess and compare acceptance levels between the three sub-regions of the URR.

Based on the above presented theoretical concepts, the scope of the present study can be defined as follows: The present study is based on a representative survey of the public (subjects) and examines public acceptance of a set of RE technologies (objects) in the three sub-regions of the URR (contexts). We hereby examine public acceptance with regard to the socio-political and the community dimension requesting general attitudes towards different RE technologies and specific attitudes towards (potential) RE plants in the neighbourhood. With regard to the study scope it is equally important to keep in mind that the population represents only one of many stakeholders and that our results are limited to the point of view of the public. We further omit the market dimension because this would require a distinct point of view: whereas the socio-political and community dimension mainly address public attitudes towards RE technologies and local RE plants; the market dimension addresses question of preferences for RE-related products (e.g. green energy tariffs, RE technologies on the household level).

\subsection{The need for more comprehensiveness and comparability}

Social acceptance of REs has been approached from various disciplinary angles and theoretical backgrounds. As the research field matures, an increasing number of publications offer overarching conceptual frameworks (Devine-Wright et al., 2017; Sovacool and Ratan, 2012), consolidating different viewpoints (Batel et al., 2013), reviewing existing literature (Fast, 2013; Sovacool, 2014), proposing new comprehensive approaches (Dermont et al., 2017), and questioning assumptions of the research field (Wolsink, 2017). Many scholars 
critique the lacking comprehensiveness and comparability of the empirical evidence so far obtained on social acceptance phenomena (cf. e.g. Batel et al., 2013; Sovacool, 2014).

With regard to comprehensiveness, most studies limit their scope to only one specific dimension of social acceptance (Sovacool, 2014), even though there is consensus that social acceptance is a multidimensional construct (Wüstenhagen et al., 2007). The often-voiced critique concerns the lack of studies which combine socio-political, community, and market acceptance or investigate the interrelations between them (Devine-Wright et al., 2017; Sovacool, 2014). Another issue raised with regard to comprehensiveness concerns the initial focus on local opposition rather than exploring the many facets of acceptance and support (Dermont et al., 2017; Devine-Wright and Batel, 2017). Scholars argue that non-opposition does not equal acceptance (Rau et al., 2012) and that a sustainable transition to REs cannot be imposed by top down decisions but requires positive appraisal as well as active action of the population (Batel et al., 2013). Indeed, community energy demonstrates much more than nonopposition, rather an approval and active support of local (renewable) energy.

Regarding comparability, there is a lack of consistency in measurement instruments for social acceptance and associated constructs (Batel et al., 2013; Rand and Hoen, 2017). In combination with an often qualitative, case-based view, comparability between studies is difficult to achieve. The lack of comparative, cross-cultural research is also addressed by Sovacool (2014) pointing out that testing hypotheses across different contexts results in stronger evidence and broader applicability of findings. Moreover, comparisons between countries allow for a broader perspective on governance (Devine-Wright et al., 2017) and the role of national energy policies for public acceptance (Sonnberger and Ruddat, 2017).

The few existing studies in the field of social acceptance research, which employ comparative approaches can be classified into three main stands: (i) those that examine the effectiveness of policy incentives for the diffusion of RE technologies (cf. e.g. Avril et al. 
2012; Deshmukh et al., 2012), (ii) those that analyse institutional settings for social acceptance mostly through indicators (cf. e.g. Toke et al., 2008; Sovacool and Ratan, 2012), and (iii) those that use empirical data to compare acceptance phenomena between cases, regions or countries. The latter group of empirical studies, which the present paper belongs to, is rather limited and addresses public acceptance, either at the community dimension through comparative, cross-country case studies (cf. e.g. Schumacher and Schultmann, 2017; Jobert et al., 2007; Warren et al., 2005) or at the national level through representative opinion polls (cf. e.g. Harold et al., 2018; Aas et al., 2014).

Existing studies have confirmed differences in public acceptance in different countries and pointed to the need for more systematic cross-cultural comparison. Schumacher and Schultmann (2017) for example found significant differences in acceptance levels, levels of support and rejection, as well as differences with regard to influencing factors for the acceptance of biogas plants by local residents in three sub-regions of the URR. Similarly, Aas et al. (2014) reported on significantly lower acceptance and trust in the UK than in Norway and Sweden with regard to high-voltage power lines. Jobert et al. (2007) found that visibility of wind turbines was more important in the French sample communities than in the German. Despite the reported differences, similarities have been equally stated by the authors, such as a low involvement of residents in decision making procedures in the study by Aas et al. (2014).

This paper takes the described shortcomings in the literature as a starting point. With regard to comprehensiveness, we explore public acceptance of a set of RE technologies comparing public attitudes at the socio-political and the community dimension. For a deeper understanding of different forms of positive acceptance and support for RE technologies we explore for the first time the relation between public acceptance, community energy and energy autonomy. With regard to comparability, our methodological approach explores public 
acceptance with regard to different acceptance objects (a set of RE technologies) in different acceptance contexts (three regions of the URR) within one study design. This contributes to a better understanding of the complex relationship between subject, object and context of acceptance. Moreover, the present paper contributes to more universal insights into public acceptance phenomena by testing hypotheses from the acceptance literature across RE technologies and national regions.

\section{MATERIALS AND METHODS}

\subsection{Study region: geography and policy frameworks for renewable energies}

The tri-national URR is composed of the territory of Alsace (France), the northwest region of Switzerland, a large part of Baden, and the south part of Rhineland-Palatinate (Germany) (cf. Figure 1). The region is populated by six million people and stretches across 21.517 square kilometres $\left(\mathrm{km}^{2}\right)$. Approximately $45 \%$ of the population lives in the German, $24 \%$ in the Swiss and $31 \%$ in the French part (Deutsch-Französische-Schweizerische Oberrheinkonferenz, 2015).

The URR is characterized by similar geographic and economic conditions and the rise of REs during the last years in all three countries. We chose the URR as study region as the initial conditions for the development of REs are rather comparable in all three sub-regions, whereas the policy framework for REs and the nationality of the inhabitants differ.

[Figure 1 about here]

The national energy sectors of the three countries differ substantially with regard to their electricity generation mix, the share and type of REs, and policies. Figure 2 shows the current 
electricity generation mix in the three countries. Due to favourable geographic conditions for hydropower, Switzerland currently has the largest share of RE with $63 \%$ (thereof $60 \%$ from hydropower run-of-river and storage plants) (Bundesamt für Energie (BFE), 2016). Germany generates $29 \%$ of electricity with REs but still has substantial shares of coal, oil, and nuclear energy (Statistisches Bundesamt (Destatis), 2017). France produces the largest share from nuclear energy (76\%) and has currently the smallest share of $16 \%$ of REs, thereof $10 \%$ from hydropower (RTE, 2016).

\section{[Figure 2 about here]}

Germany experienced by far the fastest growth of REs over the last decade: in the period from 2005 to 2015, Germany increased the share of renewables in total primary energy supply by $126 \%$, compared to $37 \%$ in France and $32 \%$ in Switzerland (OECD, 2017). The fast development of REs in Germany is mostly due to the decision to completely phase out nuclear energy by 2022 and the associated goal to increase the share of REs to $55-60 \%$ by 2035 and $80 \%$ by 2050 (BMWi and BMU, 2010). With regard to nuclear energy, Switzerland also decided a phase out but less radically - essentially no new nuclear plants will be built (Eidgenössisches Departement für Umwelt, Verkehr, und K.U., 2017), whereas in France the future of nuclear power continues to be discussed.

These different energy systems can at least partly be explained by different energy-political framework conditions. Germany's retail electricity market is liberalised and the whole sector is vertically unbundled. Whilst large fractions of non-renewable generation capacities are still owned and operated by the former 'big four' utilities (EnBW, Vattenfall, E.ON (now uniper) and RWE), the majority of renewable generation capacity is accounted for by other actors that these four utilities, including private individuals, municipal utilities, farmers and energy 
cooperatives (McKenna, 2018). The development of renewable energies in Germany has been heavily supported by the Renewable Energy Sources Act (Erneuerbare-Energien-Gesetz, EEG) in various versions since 1991 (previously the Electricity Feed-in Act, after 2000 EEG). The core of the Act is based on feed-in tariffs (FITs) for renewable electricity, combined with shared network connection and development costs between plant and network operators and priority dispatch for renewables. The FITs were initially fixed (EEG 2000, 2004 and 2009), before being supplemented by market and flexibility premiums (firstly with optional direct marketing in EEG 2012), which later became compulsory (full direct marketing, EEG, 2014) to encourage more demand-oriented generation. In the most recent versions of the EEG (2014 and 2017), tendering procedures for renewable electricity generation have been introduced (RES-LEGAL, 2017a). The most recent tendering procedures include special dispensations for community energy: they do not require planning permission and in contrast to other (commercial) bidders receive the highest awarded price (rather than the bid). Household electricity prices in Germany are around $31 € \mathrm{ct} / \mathrm{kWh}$ (Eurostat, 2018).

Switzerland has similar electricity market and energy-political framework to Germany, with liberalised retail markets and a vertically unbundled sector. It has fixed FITs, but no marketing/flexibility premiums, and direct marketing is being introduced in the context of the 2017 Energy Strategy (RES-LEGAL, 2017c). As in Germany, the costs of the renewable energy development in Switzerland are redistributed to all electricity consumers, with some exceptions; household electricity prices are around $16 € \mathrm{ct} / \mathrm{kWh}$ (EICom, 2018).

Despite also being a liberalised retail electricity market, the French system is dominated on the supply side by EDF, the state-owned incumbent utility, as well as nuclear power as mentioned above (IEA, 2016). In France, the level of the tariffs has not been as high as in Germany, priority grid access is not guaranteed, and the costs are shared by all taxpayers as 
opposed to just electricity consumers (RES-LEGAL, 2017b), with household electricity prices at around $17 € \mathrm{ct} / \mathrm{kWh}$ (Eurostat, 2018)

As we found some particularities with regard to the public perception of biogas, it is worthwhile to briefly mention the differences in national support schemes. Biogas plants have experienced a substantial growth in all three sub-regions over the last decade. With the renewable energy sources (RES) Act in 2000 (EEG, 2000), Germany strongly promoted the use of energy crops for biogas generation. This led to a strong growth of agricultural biogas plants in Germany using particularly corn as feedstock. In contrast, in Switzerland and France the use of energy crops has been rather marginal or non-existent (Schumacher and Schultmann, 2017). In consequence, the German sub-region of the URR counts 74 plants in Baden-Württemberg alone, whereas in the Swiss sub-region 14 plants, and in the French subregion five plants were operated in 2013 (Schumacher et al., 2017).

\subsection{Survey design}

The online survey was carried out in cooperation with a service provider for polls (Bilendi) from October 2015 to January 2016. The target population included all inhabitants of the URR of 16 years or older. The multi-cultural and multi-lingual conditions in the URR required the development of three linguistic versions of the questionnaire, one for each subregion. Using a parallel approach to translation, the German source questionnaire was translated independently by two translators to French. Both translations were then thoroughly discussed within the team of translators and the first author. The Swiss language version was also slightly adapted to account for linguistic differences. Finally, all three language versions were pretested in the target regions and necessary adjustments were made to increase validity.

The questionnaire composes 77 questions covering socio-demographic information as well as motives and actions, personal attitudes and beliefs, perceptions and evaluations regarding 
REs and energy autonomy (cf. Table 12 in the Appendix). The majority of questions deals with the respondents' attitudes towards the most widely used RE technologies in the URR, differentiating between large-scale and small-scale photovoltaic (PV) installations, wind power, and biogas plants. We decided to focus on these technologies because the wider population has the most direct interaction with them in the URR. Every technology was described in a short paragraph at the beginning of each section and a picture of a typical plant was shown in order to ensure that all participants had a sufficient level of information to answer the questionnaire (cf. Figure 7 in the Appendix). A separate section was dedicated to the perceptions of community energy and energy autonomy ${ }^{1}$, including aspects with regard to current or intended (financial) involvement in RE projects. Several single items dealt with the respondents' self-perceived knowledge about REs and the degree to which respondents have experiences with regard to REs in their neighbourhood.

To increase the comparability with other studies, all items and constructs were based as far as available on existing publications on the acceptance of various RE technologies (cf. e.g. Wüste 2013; Schweizer-Ries, 2010, Rau and Zoellner 2008; Griesen, 2010; Bertsch et al., 2016). Some scales needed slight adaptation to the study context; some were newly developed by the authors based on theoretical concepts from the literature. A list with all items is displayed in Table 12. Most questions were answered on a five-point Likert-scale to determine the degree to which the respondents agreed or disagreed with a proposed statement; a few questions also allowed for free-text answers. The option "don't know” was introduced wherever appropriate in order to avoid respondents choosing the "comfortable centre" ("I am undecided" or "neutral") of the unevenly-numbered Likert-scale. Because of the "don't

\footnotetext{
${ }^{1}$ For energy autonomy the first question related to familiarity with the term. Subsequent questions related to the desirability and scales at which energy autonomy might be strived for. Before these subsequent questions, a short explanation of the term energy autonomy was given, in order to ensure that the participants were informed about the concept.
} 
know" option, the sample size may differ for certain questions and analyses. At the end of the questionnaire, the respondents were asked to leave additional free text comments.

\subsection{Sample characteristics and representativeness}

The final sample contains 1,489 units of analysis and is representative relating to age and sex for all three sub-regions on the level of administrative districts (i.e. Landkreis in Germany, arrondissement in France, and Kanton in Switzerland). Of these, 33.2\% live in Germany $(n=495), 33.6 \%$ in France $(n=501)$, and $33.1 \%$ in Switzerland $(n=493)$. Table 2 compares the socio-demographic characteristics of the sample to population statistics of the three sub-regions.

[Table 2 about here]

Comparison with the statistical data reveals that the sample distribution represents the population quite precisely. However, some deviations with regard to employment and age classes are apparent. The strongest deviation was detected for the employment rate with an overrepresentation of the working population in France and Germany by 14.6 percentage points (pp) and $2.8 \mathrm{pp}$ respectively and an underrepresentation in Switzerland by $5.1 \mathrm{pp}$. However, tests showed that there are no statistically significant differences between employed and unemployed respondents with regard to acceptance levels of different technologies. Another mentionable deviation was found in the age class ' $36-55$ years' in the German and French sub-sample, which is slightly underrepresented by 4.1 and 4.3 pp respectively. Also, a slight overrepresentation of the population class ' $16-35$ years' by $4.4 \mathrm{pp}$ was found in the Swiss sub-sample. Moreover, homeowner rates diverge slightly from the population statistics 
in all three sub-regions. This might also result from regional particularities of the URR, however, as the data for homeowner-rates refers to the national level. We consider the later deviations as rather negligible (below $3 \mathrm{pp}$ ) and conclude that the sample is a good representation of the population living in the three sub-regions of the URR. We however stress the fact that the obtained data does not claim representativeness for the three countries belonging to the URR.

\subsection{Data preparation and analysis}

The analysis of the survey data was carried out with the statistics Software SPSS (Version 21). To avoid measurement errors, the data was critically reviewed and units of analysis with a processing time less than four minutes (speeders) were removed ( $8 \%$ of the dataset). All reported findings of significant differences between group means were tested using either t-tests or $\mathrm{F}$ statistics. Unless otherwise stated, tests were conducted to a significance level of $0.5 \%$.

The questionnaire contained several latent constructs which were measured by scales of several items. Table 3 lists all constructs and a short description of their meaning; the respective items are reported in Table 12. All constructs were tested by an item analysis to assess internal consistencies (Table 4). In the overall sample, all values of Cronbach's $\alpha$ exceeded the recommended threshold of 0.70 (Bühner, 2011). In the French sub-sample, however, there were some slight deviations with regard to the constructs 'advocacy of renewable energies' $(\alpha=0.626)$ and 'advocacy of energy autonomy' $(\alpha=0.664)$. The three constructs were still used, prioritizing conceptual comprehensiveness over internal consistency in the selection of scales.

[Table 3 about here]

[Table 4 about here] 


\section{RESULTS AND DISCUSSION}

\subsection{H1: REs generally enjoy high public acceptance for future energy generation.}

In line with other studies (e.g. Gamma et al., 2017; Bertsch et al., 2016; Zoellner et al., 2008), our results show that on the socio-political dimension REs are widely supported by the population in all three sub-regions for future energy provision (Figure 3). We found that solar energy enjoys highest approval with more than $85 \%$ of respondents being in favour. Bioenergy and geothermal energy rank lowest amongst the REs, with the exception of the French sub-sample, where hydropower ranks significantly lower. This comparatively negative evaluation of bioenergy fits the findings of Butler et al. (2013) and Devine-Wright (2003), who found that bioenergy was associated with fossil fuels and often not recognized as RE source. Non-REs lag far behind with less than 13\% approval. In particular, coal suffers from a low popularity. This confirms the results of other studies, which show a decline in acceptance of this energy carrier in Germany and increasing proportions of the population in favour of a complete phase out (Schumann et al., 2016).

[Figure 3 about here]

\subsection{H2: There is public disposition to act towards RE plants in the neighbourhood.}

We further analysed acceptance levels and disposition to act by using the definition of acceptance proposed by Schweizer-Ries et al. (2008) (cf. section 2.1). To measure the four levels of acceptance, we formulated them into three items. Firstly, the appraisal of a local plant was assessed by the item "How positive or negative do you rate small-scale PV/largescale PV/wind turbines/biogas plants in your neighbourhood?" on a five-point Likert scale with $1=$ "very negative" and $5=$ "very positive" as anchors (cf. Table 12). Secondly, we 
applied a filter on the first question to assess the action-oriented level of acceptance: in case of a positive appraisal, the successive item asked for the respondent's disposition to actively support a plant in the neighbourhood. In case of a negative appraisal, the respondent's disposition to actively oppose a plant in the neighbourhood was subsequently assessed (cf. Table 12, item 'active support' and 'active resistance' ). ${ }^{2}$ Figure 4 shows the results by subregion and technology.

\section{[Figure 4 about here]}

A visual inspection of Figure 4 revealed a similar rank order of acceptance levels for the different technologies in all three sub-regions. Small- and large-scale PV plants are widely accepted, with $78 \%$ and $60 \%$ of support respectively on average for the URR. The highest rejection and resistance was revealed for wind and biogas plants, with $22 \%$ and $20 \%$ opposition respectively on average for the URR.

To test for differences between the sub-regions, we used a one-way ANOVA (Table 5) which demonstrated significant differences in mean acceptance values for all technologies, except for large PV plants. Post hoc tests further revealed significantly lower appraisal of small-scale PV and wind energy plants in the French compared to the German and Swiss subregion. Moreover, the mean acceptance values were lower in the French than in the other two sub-samples for most technologies. Especially for wind energy there was low acceptance and a high threat of active resistance against local projects in France. Based on the literature, we assume this to be due to the historic "anti-wind-energy movement" in France, which saw the development of wind energy as a major threat to the "patrimoine" (national heritage) of the

\footnotetext{
2 '(Active) support' is a sub-quantity of '(passive) approval', and '(active) resistance' a sub-quantity of '(passive) rejection'.
} 
French landscape (cf. Jobert et al., 2007). Generally, the data revealed that French respondents were more critical towards REs than German and Swiss respondents.

A notable exception was the perception of biogas plants in Germany, which revealed the highest level of rejection compared to all other technologies and sub-regions. Whereas in the French and Swiss sub-sample biogas was similarly rated to wind energy, biogas ranked lowest of all technologies in the German sub-sample. From the analysis of the national policy on biogas (cf. section 3.1) and the literature (Schumacher and Schultmann, 2017), we assume that the special path Germany has taken with regard to subsidizing biogas plants running on energy crops has negatively influenced public acceptance in Germany.

[Table 5 about here]

\subsection{H3: General public acceptance (socio-political dimension) exceeds public acceptance of plants in the neighbourhood (community dimension).}

We tested for differences in public acceptance with regard to REs in general (sociopolitical dimension) and acceptance of plants in the neighbourhood (community dimension) across sub-regions and technologies. The questionnaire discriminated between general attitudes (cf. Table 12, item 'general appraisal of REs') and attitudes relating to locally installed RE plants in the vicinity (cf. Table 12, item 'acceptance of local plants'). In analogy with other studies, vicinity was defined as a one kilometre $(\mathrm{km})$ radius from the respondents' homes (cf. Hübner and Hahn, 2013; Musall and Kuik, 2011).

Table 6 shows the results for the t-test to compare public acceptance on the socio-political and the community dimension by sub-region and technology. As hypothesized, a significant difference was detected for all technologies and sub-regions. Cohens $d$ further revealed that for large-scale technologies (large PV, wind, and biogas plants) the effect was medium to 
large (Cohens d between 0.44 and 0.78 ) in all three sub-regions, whereas the effect was small to medium (Cohens d between 0.13 and 0.58 ) for REs in general and small scale PV plants in particular. Another notable result was that for small PV plants public acceptance on the community dimension was higher than on the socio-political dimension, whereas for all other technologies acceptance on the socio-political dimension was higher. A possible explanation for this result is that small PV plants are likely to be (fully) owned by the respondents, whereas the respondents could at most have a share in large PV, wind, and biogas plants, but are unlikely to own them outright. Hence this finding might be explained by the fact that people are more likely to accept a technology if they personally benefit from it (cf. section 4.6). To further assess the role of (co-) ownership for public acceptance, we analysed if respondents that either own an RE plant, are otherwise financially involved or are part of an energy cooperative, reported higher public acceptance of local RE plants than respondents that are not. A significant difference was detected with regard to the community dimension for all technologies and hence confirmed the positive effect of (co-)ownership on public acceptance for local RE plants.

[Table 6 about here]

\subsection{H4: Public acceptance of RE plants is influenced by the distance of the plant to the respondent's home.}

To approach the problem, we firstly assessed if distance to RE plants was important for the different technologies at all. Table 7 displays the results to the question "To what extent is the distance between your house/apartment and a small-scale PV/large-scale PV/wind energy/biogas plant important to you?" by answer category, sub-region, and technology. The 
data revealed strong differences between technologies: Proximity was especially important for wind and biogas plants with more than half of the respondents desiring a minimum distance to their homes, whereas the distance to small-scale PV was not relevant for the majority of respondents. Also, sight-contact was named more often as a relevant issue for large scale installations than for residential small-scale PV. We therefore conclude that the relevance of proximity depends on the technology in question as larger plant sizes are associated with higher local impacts. Looking at the literature, there is strong evidence that the distance to RE plants plays a role for public acceptance. Van der Horst (2007) states that proximity to a proposed RE project has a strong influence on local attitudes, even though the nature and extent of this influence varies according to the local context. Also some practitioners consider distance to settlements and the scenic value of a countryside in their studies on wind potentials (e.g. Jäger et al., 2016 for Baden-Württemberg, Germany; Höltinger et al., 2016 for Austria).

\section{[Table 7 about here]}

Those respondents who indicated that RE plants should keep a minimal distance from their homes (cf. Table 7) were subsequently asked to specify this distance in km. Figure 5 displays the cumulated relative frequencies of the desired distance by technology. The rank order of the technologies was the same in all three sub-regions, with the smallest desired distance for small-scale PV and the largest for biogas plants. These results are in line with those reported by Bertsch et al. (2016), who found the same rank order of technologies for a representative sample in Germany. However, in their study Bertsch et al. (2016) reported considerably 
smaller desired mean minimal distances for solar PV modules, wind power stations, and biomass power plants. ${ }^{3}$

A further strand of research is concerned with the visual effects of RE on the landscape, including aspects such as the 'quality' of the landscape and the visibility (or not) of technologies (e.g. Molnarova et al., 2012; Wolsink, 2018). The question of landscape quality has been explored with surveys of landscape photographs, whereby participants are required to rate these on a quantitative scale (e.g. Roser, 2011; Sereschine, 2017a; Sereschine, 2017b). Visibility is more closely related to the proximity of technologies and the extent to which they (are perceived to) infringe on the local landscape (e.g. Van der Horst, 2007; Bertsch et al., 2017; Wolsink, 2018). Betakova et al. (2015) for example found differences in public acceptance of wind turbines with regard to the perceived quality of the landscape. More precisely, they identified an upper threshold, above which the negative visual impact of wind turbines disappears: $10 \mathrm{~km}$ for the most attractive and $5 \mathrm{~km}$ for the least attractive landscape. Comparing this to our findings, at $5 \mathrm{~km}$ distance $65 \%$ and at $9 \mathrm{~km}$ or more $81 \%$ of respondents would accept a wind energy plant in their vicinity. However, the concepts are distinct as Kontogianni (2014) suggests that "The ensuing tension between visual intrusion and proximity is resolved in the concept of visibility." Despite these common themes, this research field is highly heterogeneous: on the one hand this encourages widening the scope of this research to consider additional perspectives, on the other hand it highlights the lack of a common theoretical framework in this area (Leibenath \& Lintz 2018).

[Figure 5 about here]

\footnotetext{
${ }^{3}$ Because of different research designs of the studies (e.g., sampling, items and scales), a deeper interpretation of the differences between the reported numbers is not reasonable.
} 


\subsection{H5: Public acceptance of $\mathrm{RE}$ plants is higher among respondents with previous experience with RE projects.}

We further hypothesized that the acceptance of respondents already living with a plant in their vicinity might exceed the acceptance of those without. We therefore asked respondents to indicate whether they were aware of RE plants installed in their neighbourhood (Table 8) and conducted a t-test to compare public acceptance between respondents with and without RE plants in their direct vicinity (Table 9). Large differences between the sub-samples were found with regard to the number of respondents already living next to RE plants: in Germany $62 \%$ indicated living with some type of RE plant in their vicinity, whereas in Switzerland $46 \%$ and in France only 19\% did so.

[Table 8 about here]

The t-Test to compare public acceptance between respondents with and without RE plants in their direct vicinity revealed statistically significant differences on the level of the URR for all technologies, except for biogas plants. On the level of the three sub-regions, however, significant differences could not be statistically proven for all cases, which could be due to small sample sizes in some of the sub-groups.

[Table 9 about here]

To further explore the role of experiences with RE plants, we analysed the relationship between experience and desired distance. We found that the average reported desired distance to a local RE plant was lower for respondents with a plant in a $1 \mathrm{~km}$ radius than for 
respondents without. However, due to the small sizes of participants with plants in a $1 \mathrm{~km}$ radius, the effect was only statistically significant for small PV plants, being the largest subsample. Furthermore, respondents with an equivalent plant in a $1 \mathrm{~km}$ radius were less likely to reject such a plant in their vicinity than respondents without. On the level of sub-regions, we made a similar observation: the average desired distance to an RE plant was significantly larger in the French $(4.8 \mathrm{~km})$ compared to the Swiss $(3.9 \mathrm{~km})$ and the German $(3.6 \mathrm{~km})$ subregion (cf. Figure 5). Hence, we see further empirical evidence to confirm our hypothesis that public acceptance is higher among respondents with previous experiences with the respective technology.

One likely explanation from the literature is the "reversed distance-decay relationship" (Sonnberger and Ruddat, 2017), which states that people without previous experience with RE plants in their vicinity tend to overestimate local impacts and therefore desire a larger distance to their homes. These findings are also in line with those of Warren et al. (2005) and van der Horst (2007), who both observed that opposition to wind farms was lower, the closer respondents lived to a wind turbine. A similar effect but in the other direction was observed by Fast (2013), who noted the high level of protest in the UK compared to the relatively low level of installed wind capacity, also known as the "mythology of the countryside" (Toke et al., 2008). These studies (including our study), however, cannot explain the causal relationship: it is both possible that either experience positively influenced public acceptance or that RE projects were sited in areas where public acceptance was already high. To understand how experience influences public acceptance over time, longitudinal data is necessary. So far only very few studies have done so. Wolsink (2007) analysed data of 16 sample points along different phases of project planning and found that attitudes are not static but developing over time. He describes a U-shaped development with high public acceptance when people are not confronted with wind power projects in their neighbourhood, a decline of 
public acceptance during the proposal phase, and an increase of public acceptance after project implementation (provided that environmental impacts are handled adequately). Another longitudinal study was conducted by Kortsch et al. (2015) with three points of measurement in time comparing between four sites in Germany. Based on a sample of 423 respondents they observed that public acceptance remained constantly high over time but the strength of the factors influencing public acceptance changed, with the exception of a constantly strong influence of the perceived benefits on public acceptance.

\subsection{H6: Public acceptance and community energy are related to energy autonomy.}

Another specific area of interest in the current study is in the connection, if any, between public acceptance and active support of REs, community energy, and energy autonomy respectively. The term energy autonomy (Deuschle et al., 2016; Rae and Bradley, 2012; McKenna et al., 2014; 2015; 2016) is employed here to also include energy autarky (Müller et al., 2011), self-sufficiency (Deuschle et al., 2016; Balcombe et al., 2015) and integrated community energy systems (Koirala et al., 2016). Community energy is defined here as local participation in RE initiatives and is measured using the construct 'engagement for renewable energies' (cf. Table 12). This section therefore explores the findings in relation to these three aspects, with a particular focus on the links between them.

In the German and Swiss sub-sample, around $10 \%$ of respondents reported to be already engaged in community energy of some kind (cf. Table 12, item 'community energy'), compared to just $4 \%$ in the French sub-sample, whereby the differences between the countries are highly significant. These findings are in stark contrast to the willingness to get involved (cf. Table 12, item 'general active support of REs') in REs, which $43 \%$ of respondents expressed. However, only $22 \%$ thereof are actually currently involved in RE projects (cf. Table 12, item 'community energy') with significantly lower involvement in the French sub- 
sample than in the other two samples. Hence the expressed willingness strongly exceeds the actual involvement in RE projects. At least for Switzerland, these results seem to confirm insights from other studies. For example, whilst over $60 \%$ of the population (in a survey of around 1,000 people) would have an interest in participating in such projects, only $2 \%$ have already done so (Gamma et al., 2017). In France, the Renewable Energy Cooperative (REScoop, 2017) project refers to about 60 community energy initiatives. In Germany, around $46 \%$ of RE capacity can be classified as community energy and is owned by private individuals and farmers (Klaus Novy Institut e.V. \& trend:research, 2011) and 718 energy cooperatives have been founded since 2006 (DGRV, 2014).

Regarding energy autonomy, $42 \%$ of the respondents stated that they are familiar with the term itself (cf. Table 12, item 'familiarity with energy autonomy'), whereby this fraction differed strongly between regional samples and levels of education. Surprisingly, in the French sub-sample with $63 \%$ a lot more respondents were familiar with the term than in the German and Swiss sub-sample with $35 \%$ and $28 \%$ respectively. We however assume that the extremely high familiarity of French respondents might be due to a wrong understanding of the term 'energy autonomy'. Due to the structure of the energy sector in France (cf. section 3.1), energy autonomy might be associated with the exclusive use of domestic energy sources for the country as a whole, including non-renewable sources, such as nuclear energy. In addition, we found significant differences with regard to the respondent's sex and year of education: $51 \%$ of male respondents claimed to be familiar with the term compared to just $34 \%$ of females, and respondents with more years of education were more likely to be familiar with the term than people with fewer years. Ultimately, familiarity seems to play an important role in the general evaluation of energy autonomy. People who already were familiar with the term evaluated approaches to more energy autonomy significantly more positively. Furthermore, people who were already involved with RE for environmental 
reasons, showed an interest in getting financially involved or were willing to actively support RE, were significantly more often familiar with the concept and rated concepts for more energy autonomy significantly more positively. Hence, we found empirical evidence that engagement for REs and advocacy of autonomy are related concepts.

Generally, there was a strong spontaneous approval of approaches to local energy autonomy in all three sub-regions, with a significantly higher approval in the German than in the Swiss and French sub-samples. Respondents with an RE plant in their neighbourhood approved concepts for more local energy autonomy significantly more positively than those without. Even though familiarity with energy autonomy seems to play an important role, many respondents indicated a spontaneous positive appraisal without a deeper knowledge of the concept. Overall, it is difficult to compare these results with the literature, as to the authors' knowledge very few if any studies have analysed these relationships.

A further question asked which scales were considered sensible to achieve energy autonomy (Figure 6). With the exception of Switzerland, where at least every third respondent stated their preference for energy autonomy at the Canton or national level, the preferred scales were at or below the regional level. Especially the level of village/municipality/city was selected as being most favourable, in most cases over twice as favourable as the other levels. This roughly corresponds to findings in the literature where projects aim at a local energy autonomy at the municipality level (cf. McKenna et al., 2014; 2015; McKenna, 2018).

\section{[Figure 6 about here]}

Having examined community energy and energy autonomy individually, attention is now turned to the relationships between those concepts. Table 10 shows the correlations between 
the three constructs 'advocacy of renewable energies', 'engagement for renewable energies' and 'advocacy of energy autonomy'. The results show that:

- For 'advocacy of energy autonomy' and 'advocacy of renewable energies', there is a significant moderate positive correlation on the level of all three sub-regions and the URR as a whole.

- For 'advocacy of energy autonomy' and 'engagement for renewable energies', there is a significant but very weak correlation, on the level of the German sub-region and the URR as a whole.

- For 'advocacy of renewable energies' and 'engagement for renewable energies', there is a significant but very weak correlation for the French and German sub-region and the URR as a whole.

The first finding is hardly surprising, given that higher levels of energy autonomy are typically achieved with more local RE technologies. It seems reasonable to suppose that if people accept one of these, they generally accept both. The second finding is more interesting, however, as it points to a very weak relationship between 'approval of energy autonomy' and active 'engagement for renewable energies'. It also points to acceptance of REs as a prerequisite for energy autonomy, but not necessarily an active engagement - even though it is difficult to derive causality from any correlation. The third finding seems to suggest that, with the exception of Switzerland, advocacy and engagement of RE go hand in hand. In other words, the 'approval' and 'support' groups in Figure 4 are not nearly as distinct as the 'rejection' and 'resistance' ones. This would seem to confirm the results of Musall and Kuik (2011), who found that, compared to a case without community ownership (or co-ownership) the level of local acceptance in the local community is higher with it. There are also local benefits that can motivate German municipalities towards energy autonomy through community energy projects, such as tax revenues, environmental awareness and independence 
from private utilities (Engelken et al., 2016). Overall, then, the findings would seem to confirm what Fast (2013) highlights as the role of public acceptance in "the guiding narrative of energy independent regions in Austria and Switzerland", whereby these initiatives act to "bind residents more tightly to existing municipal or territories, in effect hardening these boundaries".

[Table 10 about here] 


\section{SUMMARY OF RESULTS AND COMPARISON TO RELATED WORK}

In this section we compare our results for $\mathrm{H} 1$ to $\mathrm{H} 5$ with those of related studies from the literature. With regard to $\mathrm{H} 6$, the authors are not aware of any related literature that empirically examines the relationship between public acceptance and community energy to energy autonomy. Hence the exploration of this topic represents one of the novelties of this work and is therefore not discussed in this sub-section.

The comparison of our findings with the literature aims at validating our results and further deepening our understanding of public acceptance phenomena in different countries and for different technologies. To this end, we selected empirical, peer-reviewed studies on public acceptance of RE technologies and associated infrastructure, which address at least one of our hypotheses. The list of studies represents an illustrative selection (substantial reviews have been provided for example by Upham et al. (2015); Fast (2013), Gaede and Rowlands (2018)).

H1 was confirmed by the large majority of examined studies. Most of them drew this conclusion through their own empirical results; some of them, however, confirmed H1 without testing it empirically. Moreover, we found a particularity with regard to bioenergy. Upreti (2004) and Upreti and van der Horst (2004) find that there is substantial public opposition with regard to biomass. Upham \& Shackley (2007) confirm a generally high public acceptance for REs but mentions prevailing doubts of the public regarding bioenergy because of environmental concerns. This also fits our own empirical data and we hence conclude that H1 holds true for different contexts with the exception of bioenergy, being the least publicly accepted RE technology.

With regard to H2, the findings of the literature are less conclusive. Kortsch et al. (2015) and Kontogianni et al. (2014) did not find active opposition in their study regions for wind 
and bioenergy, whereas Upreti (2004) as well as Schumacher and Schultmann (2017) reported active resistance by local residents towards nearby biogas plants in the United Kingdom and the three sub-regions of the URR. Hence, the existence of local opposition cannot be simply assumed but requires deeper analysis. We conclude that local opposition is not an inevitable fact because of the inevitable impacts of RE technologies, but depends on context related factors, such as perceived costs and benefits from a local plant as well as perceived fairness (for a comprehensive review of factors influencing acceptance of REs see Perlaviciute and Steg (2014)). With regard to active support, Schumacher and Schultmann (2017) assessed and subsequently confirmed active disposition to support nearby biogas plants in the URR by local residents. Musall and Kuik (2011) found that active support in form of co-ownership led to higher public acceptance towards wind energy in general as well as nearby installed wind turbines. Many studies, however, provide little information on supportive action by the public, which again underlines the critique of Batel et al. (2016) that former research has mostly focused on public opposition and neglected the multiple facets of support.

H3 was unanimously confirmed by all selected studies including our own results. Even though some authors acknowledge that they found empirical evidence for NIMBY attitudes (Warren et al., 2005; Kontogianni et al., 2014; Upreti and van der Horst, 2004), it seems a common understanding that NIMBYism is not appropriate to explain differences between acceptance on the general the community level (cf. also section 2.1). Sütterin and Siegrist (2017) argue that the evaluation-gap might be due to an overly positive estimation of REs when judging them from an abstract point of view. Several other authors share the opinion that local acceptance is usually lower as a result of inadequate implementation processes on the community level. Identified shortcomings might be lacking involvement of residents in planning and decision making (Zoellner et al., 2008), lacking common understanding of the 
project and missing coordinated action (Upreti, 2004), as well as a lack of perceived fairness (Sonnberger and Raddat, 2017).

H4 was confirmed by the literature, except by Petrova (2016) who compared public acceptance of three communities in the US and found that those situated closest to wind turbines expressed the highest level of support. Petrova (2016, p. 1290) concludes that proximity cannot be "the only explanatory factor" and suggests that public acceptance depends on four larger categories of influencing factors, namely visual/landscape, socioeconomic, environmental and procedural aspects. Hence, H4 does not hold true for all contexts, even though the majority of studies, including the present study, found some significant effect of distance for the public acceptance of RE plants.

H5 was confirmed by the majority of reviewed studies but not all. Warren et al. (2005) reported that the expected impacts of the local windfarm (in particular visual impact and noise) did not unfold as expected and hence public acceptance increased after the local wind farm was built. Kontogianni et al. $(2014$, p. 176) in contrast state that "experiencing wind farms seems to affect positively public perceptions only marginally" and further state that a significant part of respondents showed lower acceptance after having experienced wind farms themselves. Hence, even though we saw strong empirical evidence in our data, we cannot generally accept H5. We further conclude from the literature that not only experiences but also the experienced impacts might play a role. Hence, if the experienced impacts exceed the expected impacts, public acceptance might reduce with previous experiences.

To summarise the above, Table 11 provides an overview of the findings from the literature and our own study results.

[Table 11 about here] 


\section{CONCLUSIONS AND POLICY RECOMMENDATIONS}

The data revealed high levels of general public acceptance of REs in all three sub-regions, with lower overall levels in the French sub-regions. This is probably related to the less favourable framework conditions (RE-policies and electricity prices) in this country (cf. section 3.1), as well as the lower level of experience with community energy and energy autonomy (cf. section 4.6). The low public acceptance of biogas plants in the German subregion further demonstrates that public acceptance is not only dependent on the technology in question but in particular on the configuration of such a plant on the community level. Policy makers should hence be aware of potential consequences for public acceptance when setting framework conditions to foster specific technologies or plant designs.

Furthermore, the assumed gap between public acceptance in the community and sociopolitical dimensions was confirmed for all technologies and sub-regions. Hence, policy makers should be aware of the difference between general attitudes on REs on the sociopolitical and attitudes towards specific plants on the community dimension. Hence, opinion polls on the national level cannot not be used as a decision basis for local RE projects as the object of acceptance is simply different. Whereas opinion polls assess public acceptance of RE technologies as such, the acceptance of specific RE projects needs to be assessed on a case by case basis including the project's inherent characteristics (such as ownership structure, participation possibilities, siting etc.).

Moreover, we found empirical evidence that (co-) ownership of local plants has a positive effect on public acceptance. It is therefore recommendable to involve the population as owners and operator of RE plants, also beyond small PV-plants. Our findings and experience in Germany have demonstrated the link between community energy and public acceptance. Policy measures aimed at promoting RE therefore need to consider this fact, for example in 
providing special conditions for community energy in the context of tendering processes (cf. section 3.1).

With regard to proximity, we conclude that proximity is not an exclusion criterion but must be seen in the local context, which is characterized by a set of additional factors influencing public acceptance. Based on our findings, we still recommend that policy relating to site selection should take into account the specific characteristics of the technologies and large scale RE plants should respect minimal distances to residential areas.

We also found that respondents with experiences with RE plants in their direct vicinity showed higher public acceptance on average. Moreover, the average desired distance to an RE plant was significantly smaller for respondents already living with a plant in their vicinity. We hence conclude that former experiences are favourable for public acceptance as these experiences provide a more realistic picture of the actual impacts of local RE plants, which otherwise tend to be overestimated. Therefore, accurate information on the actual costs and benefits of REs for the community and the individual are important to achieve public acceptance of REs. Also, a transfer of experience between countries, such as the Germany Bioenergy Villages or the Swiss Energy Regions would seem to be a promising policy to enable people to get a more accurate picture of the impacts of different RE technologies.

Finally, the data revealed significantly more engagement in community energy $(10 \%)$ in Germany and Switzerland than in France (4\%). As this is probably related to the more favourable institutional setting in the two former countries, removing barriers in France such as achieving priority grid access for RE plants might be one way to indirectly improve public acceptance. Despite an overall engagement of about $9 \%$, however, $43 \%$ of the sample expressed a willingness to get involved. Hence, there is a gap between the desire to be involved and the actual degree of participation. This offers opportunities for political actors and private project owners to increase public acceptance by offering respective participation 
possibilities to the population. To close this gap, there might also be a need to inform individuals about the possibilities to get financially involved in RE, e.g. through information campaigns and advertisements on the possibilities of community energy.

\section{Acknowledgements}

This work was performed in the context of the research projects 'OUI Biomasse' (Innovations for sustainable biomass utilization in the Upper Rhine Region) and URCforSR (Upper Rhine Cluster for Sustainability Research) both financed by the European Regional Development Fund (ERDF) and other national co-financiers. The authors thank the ERDF and the Science Offensive of the Trinational Metropolitan Upper Rhine Region for their financial support. Moreover, the authors are grateful to two anonymous reviewers for their helpful comments on a previous version of this article. Finally, the authors thank Wojciech Kata, and Natalie Lanzrath who have supported the study as research assistant. The usual disclaimer applies. 


\section{References}

Aas, Ø., Devine-Wright, P., Tangeland, T., Batel, S., Ruud, A., 2014. Public beliefs about high-voltage powerlines in Norway, Sweden and the United Kingdom: A comparative survey. Energy Research \& Social Science 2, 30-37. doi: 10.1016/j.erss.2014.04.012.

Agora Energiewende, 2016. Energy Transition in the Power Sector in Europe: State of Affairs in 2015. https://www.agora-energiewende.de/en/publications/energy-transition-in-thepower-sector-in-europe-state-of-affairs-in-2016-2/ (accessed 6 September 2018).

Avril, S., Mansilla, C., Busson, M., Lemaire, T., 2012. Photovoltaic energy policy: Financial estimation and performance comparison of the public support in five representative countries. Energy Policy 51, 244-258. doi: 10.1016/j.enpol.2012.07.050.

Balcombe, P., Rigby, D., Azapagic, A., 2015. Energy self-sufficiency, grid demand variability and consumer costs: Integrating solar PV, Stirling engine CHP and battery storage, Applied Energy 155, 393-408. doi: 10.1016/j.apenergy.2015.06.017.

Batel, S., Castro, P., Devine-Wright, P., Howarth, C., 2016. Developing a critical agenda to understand pro-environmental actions: contributions from Social Representations and Social Practices Theories. WIREs Climate Change 7, 727-745. doi:10.1002/wcc.417.

Batel, S., Devine-Wright, P., Tangeland, T., 2013. Social acceptance of low carbon energy and associated infrastructures: A critical discussion. Energy Policy 58, 1-5. doi:10.1016/j.enpol.2013.03.018.

Bertsch, V., Hall, M., Weinhardt, C., Fichtner, W., 2016. Public acceptance and preferences related to renewable energy and grid expansion policy: Empirical insights for Germany. Energy 114, 465-477. doi:10.1016/j.energy.2016.08.022.

Betakova, V., Vojar, J., Sklenicka, P., 2015. Wind turbines location: How many and how far? Applied Energy 151, 23-31. doi:10.1016/j.apenergy.2015.04.060. 
BMWi (Bundesministerium für Wirtschaft und Technologie) \& BMU (Bundesministerium für Umwelt, Naturschutz und Reaktorsicherheit), 2010. Energiekonzept der Bundesregierung: für eine umweltschonende, zuverlässige und bezahlbare Energieversorgung, 28. September 2010. https://www.bmwi.de/Redaktion/DE/Downloads/E/energiekonzept2010.pdf?_blob=publicationFile\&v=3 (accessed 13 September 2018).

Breukers, S., Wolsink, M., 2007. Wind power implementation in changing institutional landscapes: An international comparison. Energy Policy 35 (5), 2737-2750. doi:10.1016/j.enpol.2006.12.004.

Bühner, M., 2011. Einführung in die Test- und Fragebogenkonstruktion, 3rd ed. Pearson, München.

Bundesamt für Energie (BFE), 2016. Schweizerische Elektrizitätsstatistik 2015 / Statistique suisse de l' électricité 2015.

Bundesamt für Statistik, 2014. Statistik der Bevölkerung und der Haushalte ( STATPOP ). Butler, C., Parkhill, K.A., Pidgeon, N., 2013. Deliberating energy transitions in the UK Transforming the UK Energy System: Public Values, Attitudes and Acceptability. UKERC, London. http://www.ukerc.ac.uk/publications/transforming-the-uk-energysystem-public-values-attitudes-and-acceptability-deliberating-energy-system-transitionsin-the-uk.html (accessed 30 July 2018).

Cohen, J., Cohen, P., West, S.G., Aiken, L.S., 2003. Applied multiple regression/correlation analysis for the behavioral sciences, 3rd ed., Mahwah, NJ, US: Lawrence Erlbaum Associates Publishers..

Dermont, C., Ingold, K., Kammermann, L., Stadelmann-Steffen, I., 2017. Bringing the policy making perspective in: A political science approach to social acceptance. Energy Policy 108, 359-368. doi:10.1016/j.enpol.2017.05.062. 
Deuschle, J., Hauser, W., Sonnberger, M., Tomaschek, J., Brodecki, L., Fahl, U., 2016. Energie-Autarkie und Energie-Autonomie in Theorie und Praxis, Zeitschrift für Energiewirtschaft 39, , 295-295.

Deutsch-Französische-Schweizerische Oberrheinkonferenz: Oberrhein/Rhin Supérieur, 2015. Zahlen und Fakten/Faits et chiffres. https://www.oberrheinkonferenz.org/de/wirtschaft/zahlenundfakten.html (accessed 6 September 2018).Deutscher Genossenschafts- und Raiffeisenverband (DGRV), 2014. Energiegenossenschaften: Ergebnisse der Umfrage des DGRV und seiner Mitgliedsverbände, Bundesgeschäftsstelle Energiegenossenschaften, Berlin, Frühjahr 2014.

Deshmukh, R., Bharvirkar, R., Gambhir, A., Phadke, A., 2012. Changing Sunshine: Analyzing the dynamics of solar electricity policies in the global context. Renewable and Sustainable Energy Reviews 16, 5188-5198. doi: 10.1016/j.rser.2012.04.020.

Devine-Wright, P., 2003. A cross-national, comparative analysis of public understanding of, and attitudes towards nuclear, renewable and fossil-fuel energy sources. In: Crossing Boundaries - The Value of Interdisciplinary Research: Proceedings of the Third Conference of the EPUK (Environmental Psychology in the UK) Network, 160-173. EPUK. Aberdeen, UK: Robert Gordon University.

Devine-Wright, P., 2009. Rethinking NIMBYism: The role of place attachment and place identity in explaining place-protective action. Journal of Community Applied Social Psychology 19, 426-441. doi:10.1002/casp.1004.

Devine-Wright, P., Batel, S., 2017. Crossing the national-local "gap": Using multiple datasets to investigate the influence of local and national identities upon the social acceptance of energy infrastructure, in: 1st International Conference on Energy Research \& Social Science. Sitges, Spain. 
Devine-Wright, P., Batel, S., Aas, O., Sovacool, B., LaBelle, M.C., Ruud, A., 2017. A conceptual framework for understanding the social acceptance of energy infrastructure: Insights from energy storage. Energy Policy 107, 27-31. doi:10.1016/j.enpol.2017.04.020.

Diekmann, A., Preisendörfer, P., 2003. Green and Greenback: The Behavioral Effects of Environmental Attitudes in Low-Cost and High-Cost Situations. Rationality and Society 15, 441-472. doi: 10.1177/1043463103154002.

EEG, 2000. Erneuerbare-Energien-Gesetz: Gesetz für den Vorrang Erneuerbarer Energien (Erneuerbare-Energien-Gesetz-EEG 2000) sowie zur Änderung des Energiewirtschaftsgesetzes und des Mineralölsteuergesetzes.

EEG, 2004. Erneuerbare-Energien-Gesetz: Gesetz für den Vorrang Erneuerbarer Energien (Erneuerbare-Energien-Gesetz-EEG 2004).

EEG, 2009. Erneuerbare-Energien-Gesetz: Gesetz für den Vorrang Erneuerbarer Energien (Erneuerbare-Energien-Gesetz-EEG 2009).

EEG, 2012. Erneuerbare-Energien-Gesetz: Gesetz für den Vorrang Erneuerbarer Energien (Erneuerbare-Energien-Gesetz-EEG 2012).

EEG, 2014. Erneuerbare-Energien-Gesetz: Gesetz für den Vorrang Erneuerbarer Energien (Erneuerbare-Energien-Gesetz-EEG 2014).

EEG, 2017. Erneuerbare-Energien-Gesetz: Gesetz für den Vorrang Erneuerbarer Energien (Erneuerbare-Energien-Gesetz-EEG 2017).

Eidgenössisches Departement für Umwelt, Verkehr, E. und K.U., 2017. Ausstieg aus der Kernenergie. https://www.uvek.admin.ch/uvek/de/home/energie/energiestrategie2050/kernenergie.html (accessed 29 September 2017).

EICom, 2018. Tarif-Rohdaten der schweizerischen Verteilnetzbetreiber. 
https://www.elcom.admin.ch/elcom/de/home/themen/strompreise/tarif-rohdatenverteilnetzbetreiber.html (accessed 26 July 2018).

Engelken, M., Römer, B., Drescher, M., Welpe, I., 2016. Transforming the energy system: Why municipalities strive for energy self-sufficiency. Energy Policy, 98, 365-377.

European Commission (2017): Report from the commission to the European parliament, the council, the european economic and social committee and the committee of the regions, Renewable Energy Progress Report, COM(2017) 57 final, Brussels, 01.02.2017.

Eurostat, 2014. Wohneigentumsquoten in ausgewählten europäischen Ländern im Jahr 2014. http://de.statista.com/statistik/\%0Adaten/studie/155734/umfrage/wohneigentumsquotenin-europa/\%0A (accessed 29 June 2016).

Eurostat, 2018. Electricity prices, Second semester of 2015-2017 (EUR per kWh). http://ec.europa.eu/eurostat/statisticsexplained/index.php?title=File:Electricity_prices,_Second_semester_of_20152017_(EUR_per_kWh).png (accessed 27 July 2018).

Fast, S., 2013. Social Acceptance of Renewable Energy: Trends, Concepts, and Geographies. Geography Compass 7. doi:10.1111/gec3.12086.

Gaede, J., Rowlands, I.H., 2018. Visualizing social acceptance research. Energy Research \& Social Science 40, 142-158. doi: 10.1016/j.erss.2017.12.006.

Gamma, K., Stauch, A., Wüstenhagen, R., 2017. 7th Consumer Barometer of Renewable Energy. http://www.iwoe.unisg.ch/kundenbarometer (accessed 29 September 2017).

GeoRhena, 2017. Kartensammlung. http://www.georhena.eu/de/Kartensammlung (accessed 29 September 2017).

Griesen, M., 2010. Akzeptanz von Biogasanlagen: Bonner Studien zur Wirtschaftssoziologie, Band 34, 1st ed. Shaker, Aachen. 
Herbes, C., Jirka, E., Braun, J. P., Pukall, K., 2014. Der gesellschaftliche Diskurs um den „Maisdeckel“"vor und nach der Novelle des Erneuerbare-Energien-Gesetzes (EEG) 2012, GAIA, 23/2, 100-108.

Höltinger, S., Salak, B., Schauppenlehner, T., Scherhaufer, P., Schmidt, J., 2016. Austria's wind energy potential - A participatory modeling approach to assess socio-political and market acceptance. Energy Policy 98, 49-61. doi:10.1016/j.enpol.2016.08.010.

Hübner, G., 2012. Die Akzeptanz von erneuerbaren Energien: Einstellungen und Wirkungen. Metropolis-Verlag.

Hübner, G., Hahn, C., 2013. Akzeptanz des Stromnetzausbaus in Schleswig-Holstein. Abschlussbericht zum Forschungsprojekt. Halle.

International Energy Agency (IEA), 2016. Energy Policies of IEA Countries: France 2016 Review. https://webstore.iea.org/energy-policies-of-iea-countries-france-2016-review (accessed 30 July 2018).

Institut national de la statistique et des études économiques (INSEE), 2015. Résultats statistiques du recensement: POP1B_-population par sexe et âge. http://www.insee.fr (accessed 09 June 2016).

Jäger, T., McKenna, R., Fichtner, W., 2016. The feasible onshore wind energy potential in Baden-Württemberg: A bottom-up methodology considering socio-economic constraints. Renewable Energy 96, 662-675. doi:10.1016/j.renene.2016.05.013.

Jobert, A., Laborgne, P., Mimler, S., 2007. Local Acceptance of Wind Energy: Factors of Success Identified in French and German Case Studies. Energy Policy 35, 2751-2760. doi: 10.1016/j.enpol.2006.12.005.

Klaus Novy Institut e.V. \& trend:research, 2011. „Marktakteure: Erneuerbare-EnergienAnlagen in der Stromerzeugung“, [Market actors: renewable energy plants in electricity 
generation], Köln. https://sverigesradio.se/diverse/appdata/isidor/files/3345/12617.pdf (accessed 13.September 2018).

Koirala, B. M., Koliou, E., Friege, J., Hakvoort, R. A., Herder, P. M., 2016. Energetic communities for community energy: A review of key issues and trends shaping integrated community energy systems, Renewable \&Sustainable Energy Reviews 56, 722-744. 10.1016/j.rser.2015.11.080.

Kontogianni, A., Tourkolias, C., Skourtos, M., Damigos, D., 2014. Planning globally, protesting locally: Patterns in community perceptions towards the installation of wind farms. Renewable Energy 66, 170-177. doi:10.1016/j.renene.2013.11.074.

Kortsch, T., Hildebrand, J., Schweizer-Ries, P., 2015. Acceptance of biomass plants-results of a longitudinal study in the bioenergyregion Altmark. Renewable Energy 83, 690-697. doi:10.1016/j.renene.2015.04.059.

Leibenath, M., Lintz, G., 2018. Governance of energy landscapes between pathways, people and politics. Landscape Research 43, 471-475. doi: 10.1080/01426397.2018.1444156.

Lucke, D., 1995. Akzeptanz. Legitimität in der “Abstimmungsgesellschaft.” VS Verlag für Sozialwissenschaften, Wiesbaden. doi:10.1007/978-3-663-09234-6.

Molnarova, K., Sklenicka, P., Stiborek, J., Svobodova, K., Salek, M., Brabec, E. 2012. Visual preferences for wind turbines: Location, numbers and respondent characteristics. $\mathrm{J}$ Applied Energy 92, 269-78. doi: 10.1016/j.apenergy.2017.11.027.

McKenna, R., Jäger, T., Fichtner, W., 2014. Energieautarkie - ausgewählte Ansätze und Praxiserfahrungen im deutschsprachigen Raum, Umwelt Wirtschafts Forum, Vol. 22, Issue 4, 241-247. doi:10.1007/s00550-014-0339-y.

McKenna, R., Herbes, C., Fichtner, W., 2015. Energieautarkie: Vorschlag einer Arbeitsdefinition als Grundlage für die Bewertung konkreter Projekte und Szenarien, 
Zeitschrift für Energiewirtschaft 39(4). doi:10.1007/s12398-015-0164-1.

McKenna, R., Merkel, E., Fichtner, W., 2016. Energy autonomy in residential buildings: a techno-economic model-based analysis of the scale effects, Applied Energy 189, 800815. doi:10.1016/j.apenergy.2016.03.062.

McKenna, R., 2018. The double-edged sword of decentralized energy autonomy. Energy Policy 113, 747-750. doi: 10.1016/j.enpol.2017.11.033.

Müller, M. O., Stämpfli, A., Dold, U., Hammer, T. (2011): Energy Autarky: A conceptual framework for sustainable regional development, Energy Policy 39, 5800-5810.

Musall, F. D., Kuik, O., 2011. Local acceptance of renewable energy—A case study from southeast Germany. Energy Policy 39, 3252-3260. doi:10.1016/j.enpol.2011.03.017.

OECD, 2017. Renewable energy (indicator). https://data.oecd.org/energy/renewableenergy.htm (accessed 17 August 2017).

Petrova, M.A., 2016. From NIMBY to acceptance: Toward a novel framework - VESPA For organizing and interpreting community concerns. Renewable Energy 86, 1280-1294. doi: 10.1016/j.renene.2015.09.047.

Rand, J., Hoen, B., 2017. Thirty years of North American wind energy acceptance research: What have we learned? Energy Research \& Social Science 29, 135-148. doi: 10.1016/j.erss.2017.05.019.

Rau, I., Schweizer-Ries, P., Hildebrand, J., 2012. Participation: The Silver Bullet for the Acceptance of Renewable Energies?. In: Vulnerability, Risks, and Complexity: Impacts of Global Change on Human Habitats Volume 3. Hogrefe.

Rau, I., Zoellner, J., 2008. Akzeptanz erneuerbarer Energien und sozialwissenschaftliche Fragen. [Acceptance of renewable energies and socioscientific questions]. Final Project Report, Otto-von-Guericke-Universität, Inst. für Psychologie I, Forschungsgruppe 
Umweltpsychologie.

Rae, C., Bradley, F., 2012. Energy autonomy in sustainable communities - A review of key issues. Renewable and Sustainable Energy Reviews 16, 6497-6506.

REN 21, 2017. Renewables 2017: global status report. REN21, Paris, France. http://www.ren21.net/wp-content/uploads/2017/06/178399_GSR_2017_Full_Report_0621_Opt.pdf(accessed 13 September 2018).

REScoop, 2017. European Tour. https://rescoop.eu/european-tour (accessed 17 August 2017).

Réseau de transport d'électricité (RTE), 2016. 2015 Annual Electricity Report. http://www.rte-france.com/sites/default/files/2015_annual_electricity_report.pdf (accessed 29 September 2017).

RES-LEGAL, 2017a. Promotion in Germany. http://www.res-legal.eu/search-bycountry/germany/tools-list/c/germany/s/res-e/t/promotion/sum/136/lpid/135/ (accessed 06 October 2017).

RES-LEGAL, 2017b. Promotion in France. http://www.res-legal.eu/search-bycountry/france/tools-list/c/france/s/res-e/t/promotion/sum/132/lpid/131/ (accessed 06 October 2017).

RES-LEGAL, 2017c. Promotion in Switzerland. http://www.res-legal.eu/search-bycountry/switzerland/single/s/res-e/t/promotion/aid/feed-in-tariff-1/lastp/396/ (accessed 06 October 2017).

Roser, F. 2011. Entwicklung einer Methode zur großflächigen rechnergestützten Analyse des landschaftsästhetischen Potenzials. Ph.D. dissertation, Dept. Architektur und Stadtplanung, University of Stuttgart. Weißensee Verlag, Berlin, Germany.

Schumacher, K., Fichtner, W., Schultmann, F., (Eds.), 2017. Innovations for sustainable biomass utilisation in the Upper Rhine Region. KIT Scientific Publishing, Reihe 
Produktion und Energie, Band 18, Karlsruhe. doi:10.5445/KSP/1000048433.

Schumann, D., Fischer, W., Hake, J.-F., 2016: Kohlenutzung und Kohleaussteig in Deutschland aus Sicht der Bevölkerung, Energiewirtschaftliche Tagesfragen 66, 18-22.

Schumacher, K., Schultmann, F., 2017. Local Acceptance of Biogas Plants: A Comparative Study in the Trinational Upper Rhine Region. Waste Biomass Valorization 8, 23932412. doi:10.1007/s12649-016-9802-Z.

Schweizer-Ries, P., 2008. Energy sustainable communities: Environmental psychological investigations. Energy Policy 36, 4126-4135. doi:10.1016/j.enpol.2008.06.021.

Schweizer-Ries, P., Rau, I., Nolting, K., Rupp, J., Keppler, D., 2010. Aktivität und Teilhabe-Akzeptanz Erneuerbarer Energien durch Beteiligung steigern. Report. https://www.tuberlin.de/fileadmin/f27/PDFs/Forschung/Abschlussbericht_Aktivitaet_Teilhabe_format. pdf (accessed 29 September 2017).

Schweizer-Ries, P., Rau, I., Zoellner, J., 2008. Akzeptanz erneuerbarer Energien und sozialwissenschaftliche Fragen. Report. http://edok01.tib.unihannover.de/edoks/e01fb09/6126382861.pdf (accessed 29 September 2017).

Seresinhe, C.I., Moat, H.S., Preis, T., 2017a. Quantifying scenic areas using crowdsourced data. Environment and Planning B: Urban Analytics and City Science 45, 567-582. doi: $10.1177 / 0265813516687302$.

Seresinhe, C.I., Preis, T., Moat, H.S., 2017b. Using deep learning to quantify the beauty of outdoor places. Royal Society open science 4. doi: 170170. 10.1098/rsos.170170.

Sonnberger, M., Ruddat, M., 2017. Local and socio-political acceptance of wind farms in Germany. Technology in Society 51, 56-65. doi: 10.1016/j.techsoc.2017.07.005.

Sovacool, B.K., 2014. What are we doing here? Analyzing fifteen years of energy scholarship 
and proposing a social science research agenda. Energy Research and Social Science1, 1-29. doi: 10.1016/j.erss.2014.02.003.

Sovacool, B.K., Ratan, P.L., 2012. Conceptualizing the acceptance of wind and solar electricity. Renewable and Sustainable Energy Review 16, 5268-5279. doi: 10.1016/j.rser.2012.04.048.

Statistisches Bundesamt (Destatis), 2017. Bruttostromerzeugung in Deutschland für 2014 bis 2016.

https://www.destatis.de/DE/ZahlenFakten/Wirtschaftsbereiche/Energie/Erzeugung/Tabel len/Bruttostromerzeugung.html (accessed 29 September 2017).

Statistisches Landesamt Baden-Württemberg, 2011. Bevölkerungsfortschreibung, Basis Zensus 2011. http://www.statistik.badenwuerttemberg.de (accessed 29 June 2016)

Sütterlin, B., Siegrist, M., 2017. Public acceptance of renewable energy technologies from an abstract versus concrete perspective and the positive imagery of solar power. Energy Policy 106, 356-366. doi: 10.1016/j.enpol.2017.03.061.

Toke, D., Breukers, S., Wolsink, M., 2008. Wind power deployment outcomes: How can we account for the differences?. Renewable and Sustainable Energy Reviews, 12, 11291147.

Upham, P., Shackley, S., 2006. The case of a proposed 21.5MWe biomass gasifier in Winkleigh, Devon: Implications for governance of renewable energy planning. Energy Policy 34, 2161-2172. doi: 10.1016/j.enpol.2005.04.001.

Upham, P., Shackley, S., 2007. Local public opinion of a proposed 21.5MW(e) biomass gasifier in Devon: Questionnaire survey results. Biomass and Bioenergy 31, 433-441. doi: 433-441. 10.1016/j.biombioe.2007.01.017.

Upham, P., Oltra, C., Boso, À., 2015. Towards a cross-paradigmatic framework of the social 
acceptance of energy systems. Energy Research \& Social Science 8, 100-112. doi: 10.1016/j.erss.2015.05.003.

Upreti, B. R., 2004. Conflict over biomass energy development in the United Kingdom: some observations and lessons from England and Wales. Energy Policy 32, 785-800. doi:10.1016/S0301-4215(02)00342-7.

Upreti, B. R., van der Horst, D., 2004. National renewable energy policy and local opposition in the UK: the failed development of a biomass electricity plant. Biomass and Bioenergy 26, 61-69. doi:10.1016/S0961-9534(03)00099-0.

Van der Horst, D., 2007. NIMBY or not? Exploring the relevance of location and the politics of voiced opinions in renewable energy siting controversies. Energy Policy 35, 27052714. doi:10.1016/j.enpol.2006.12.012.

Walker, G., 2008. What are the barriers and incentives for community-owned means of energy production and use? Energy Policy 36, 4401-4405. doi: 10.1016/j.enpol.2008.09.032.

Walker, G., Devine-Wright, P., Hunter, S., High, H., Evans, B., 2010. Trust and community: Exploring the meanings, contexts and dynamics of community renewable energy. Energy Policy 38, 2655-2663. doi: 10.1016/j.enpol.2009.05.055.

Warren, C. R., Lumsden, C., O’Dowd, S., Birnie, R. V., 2005. Green on green: public perceptions of wind power in Scotland and Ireland. Journal of Environmental Planning and Management 48, 853-875. doi: 10.1080/09640560500294376.

Wolsink, M., 2000. Wind power and the NIMBY-myth: institutional capacity and the limited significance of public support. Renewable Energy 21, 49-64. doi: 10.1016/S09601481(99)00130-5.

Wolsink, M., 2007. Wind power implementation: The nature of public attitudes: Equity and fairness instead of 'backyard motives'. Renewable and Sustainable Energy Reviews 11, 
1188-1207. doi: 10.1016/j.rser.2005.10.005.

Wolsink, M., 2017. Framing in renewable energy policies: a glossary. 1st International Conference on Energy Research \& Social Science, Sitges, Spain, 2.-5. April 2017.

Wolsink, M., 2018. Co-production in distributed generation: Renewable energy and creating space for fitting infrastructure within landscapes. Landscape Research 43, 542-561. doi:10.1080/01426397.2017.1358360.

Wolsink, M., 2018. Social acceptance revisited: Gaps, questionable trends, and an auspicious perspective. Energy Research \& Social Science 46, 287-295. doi: 10.1016/j.erss.2018.07.034.

Wüste, A., 2013. Akzeptanz verschiedener Bioenergienutzungskonzepte und Erfolgsfaktoren beim Ausbau dezentraler Bioenergieprojekte in Deutschland, 1st ed. Cuvillier, Göttingen.

Wüstenhagen, R., Wolsink, M., Bürer, M. J., 2007. Social acceptance of renewable energy innovation: An introduction to the concept. Energy Policy 35, 2683-2691. doi:10.1016/j.enpol.2006.12.001.

Zoellner, J., Schweizer-Ries, P., Wemheuer, C., 2008. Public acceptance of renewable energies: Results from case studies in Germany. Energy Policy 36, 4136-4141. doi:10.1016/j.enpol.2008.06.026. 
Energy Policy: Public Acceptance of Renewable Energies and Energy Autonomy: A Comparative Study in the French, German and Swiss Upper Rhine Region

\section{APPENDIX}

[Table 12 about here]

[Figure 7 about here] 


\section{Highlights}

- Analyse public acceptance of renewable energies across different contexts and technologies.

- Representative sample of 1,489 inhabitants of the tri-national Upper Rhine region.

- Role of proximity depends on the technology and previous experiences of the respondent.

- Public acceptance, community energy and energy autonomy are interconnected.

- Intraregional differences linked to institutional and policy frameworks. 


\section{Figures}

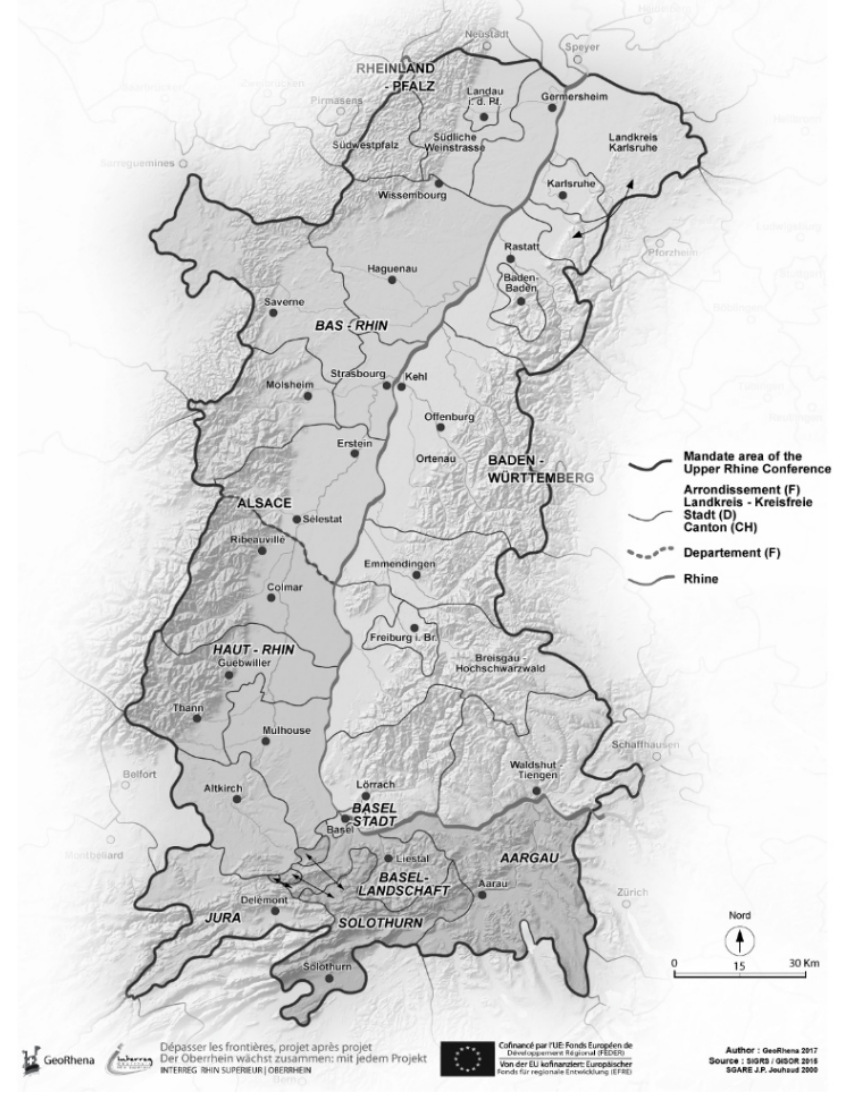

Figure 1 Map of the Upper Rhine region (GeoRhena, 2017) 


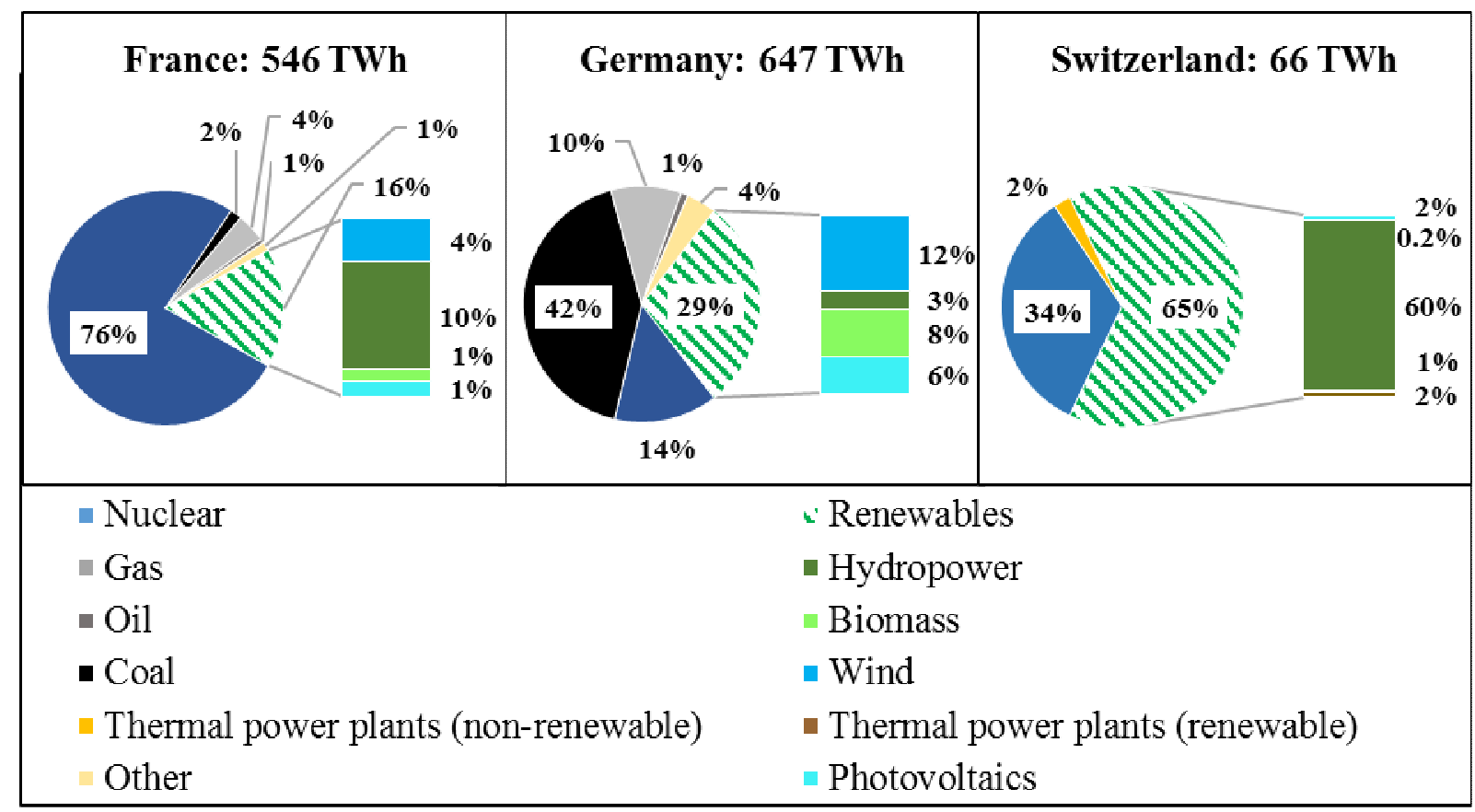

Figure 2 Electricity generation in France (RTE, 2016), Germany (Destatis, 2017) and Switzerland (BFE, 2016) in 2015

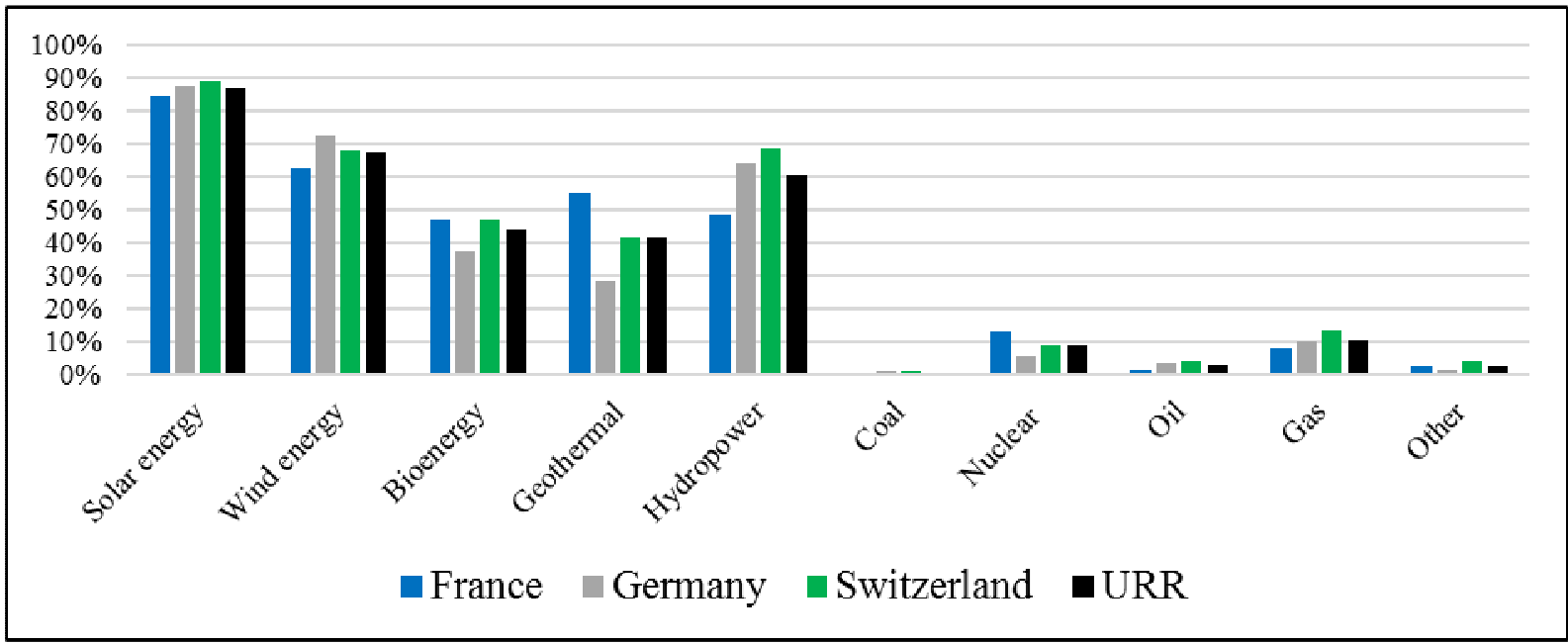

Figure 3 Frequency distribution of the answers to the question "In your opinion, which energy technologies should be preferably used in the future?"

Note: Sample sizes: $\mathrm{n}_{\text {Germany }}=495, \mathrm{n}_{\text {Switzerland }}=493, \mathrm{n}_{\text {France }}=501$ 


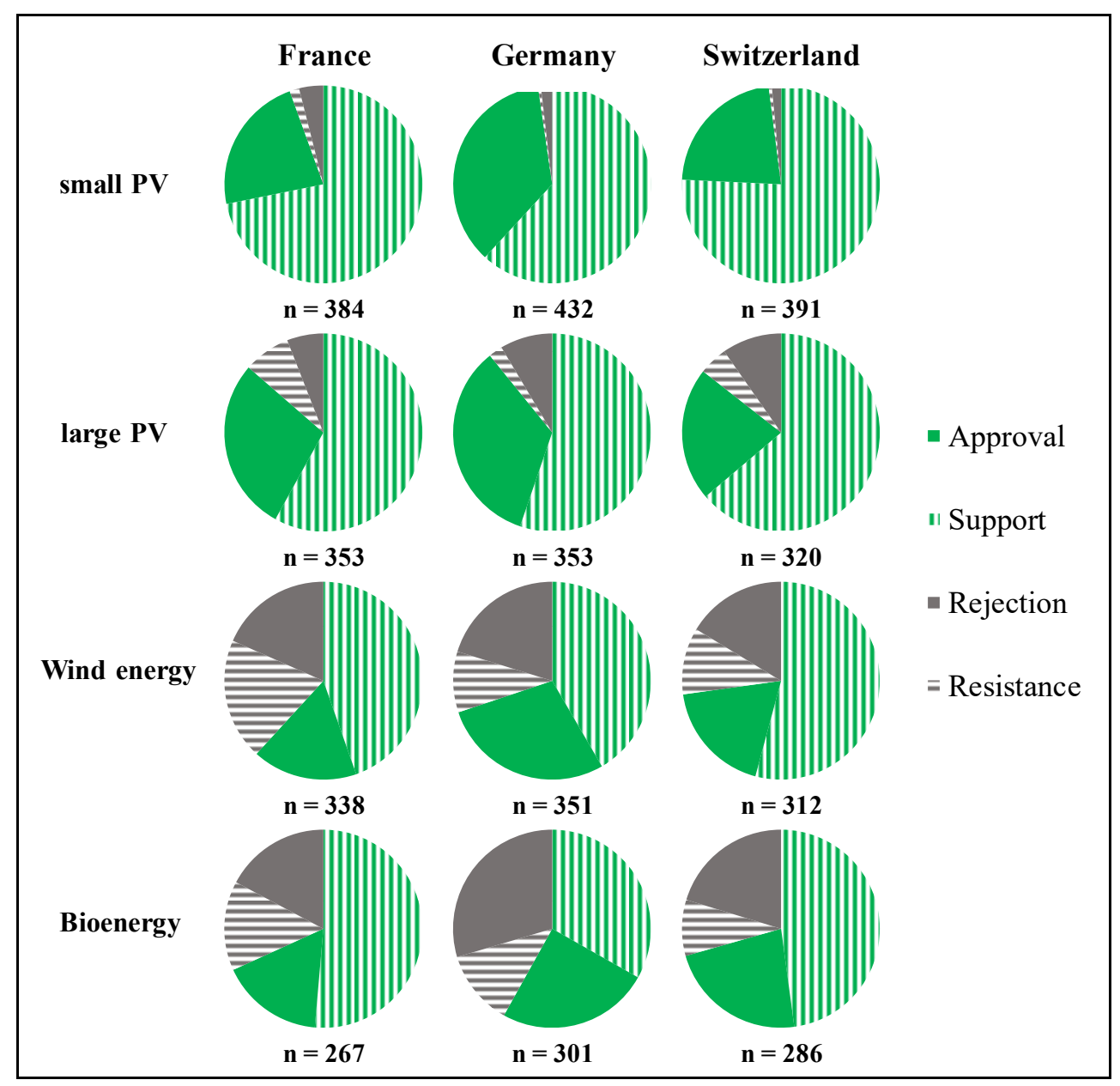

Figure 4 Levels of acceptance and disposition to act towards a plant in the neighborhood by sub-region and technology

Notes:

Categories 'approval' and 'rejection' include the categories 'support' and 'resistance' respectively.

Respondents are excluded who evaluated a plant in the neighborhood as "neutral". 


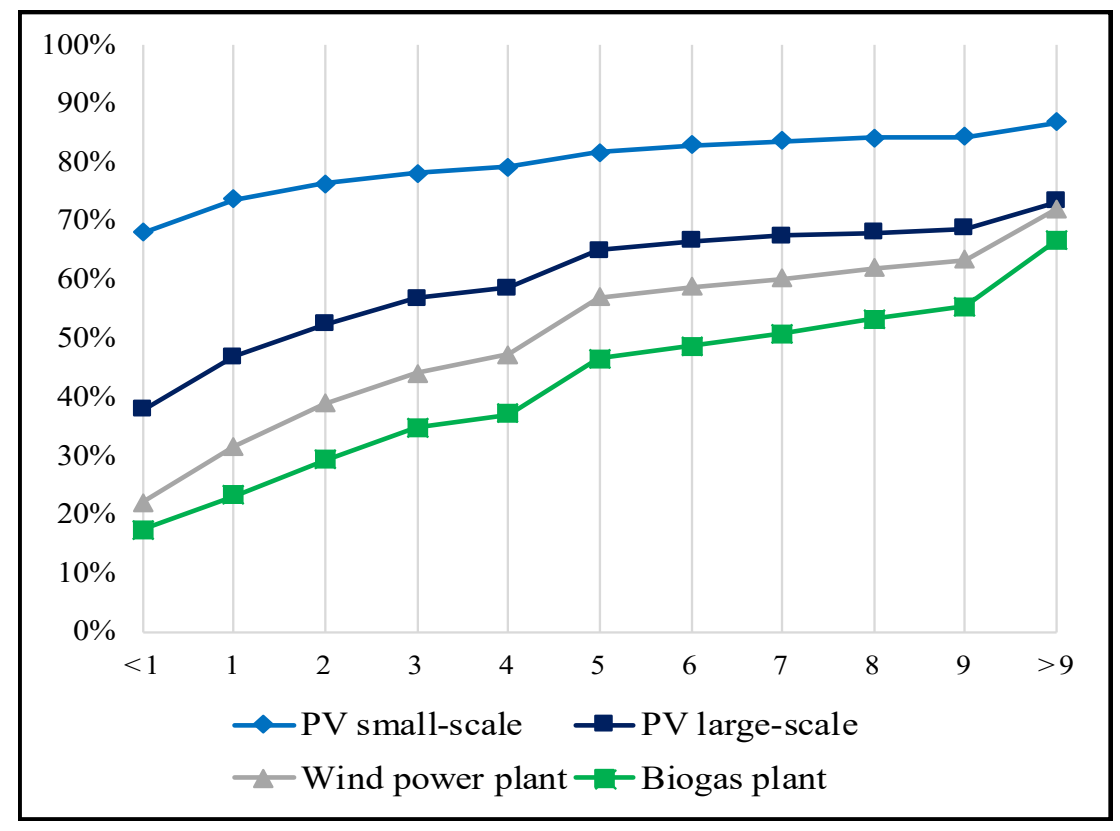

Figure 5 Cumulated relative frequencies of the desired minimum distance of REs plants in kilometre (km)

Notes:

Sample sizes: $\mathrm{n}_{\mathrm{PV} \text { small }}=1,291, \mathrm{n}_{\mathrm{PV} \text { large }}=1,090, \mathrm{n}_{\mathrm{Wind}}=1,072, \mathrm{n}_{\text {Biogas }}=992$

Includes responses "The distance of the plant to my home is not relevant for me." as $0 \mathrm{~km}$

Expressed as percentage of all responses (cf. Table 10) 


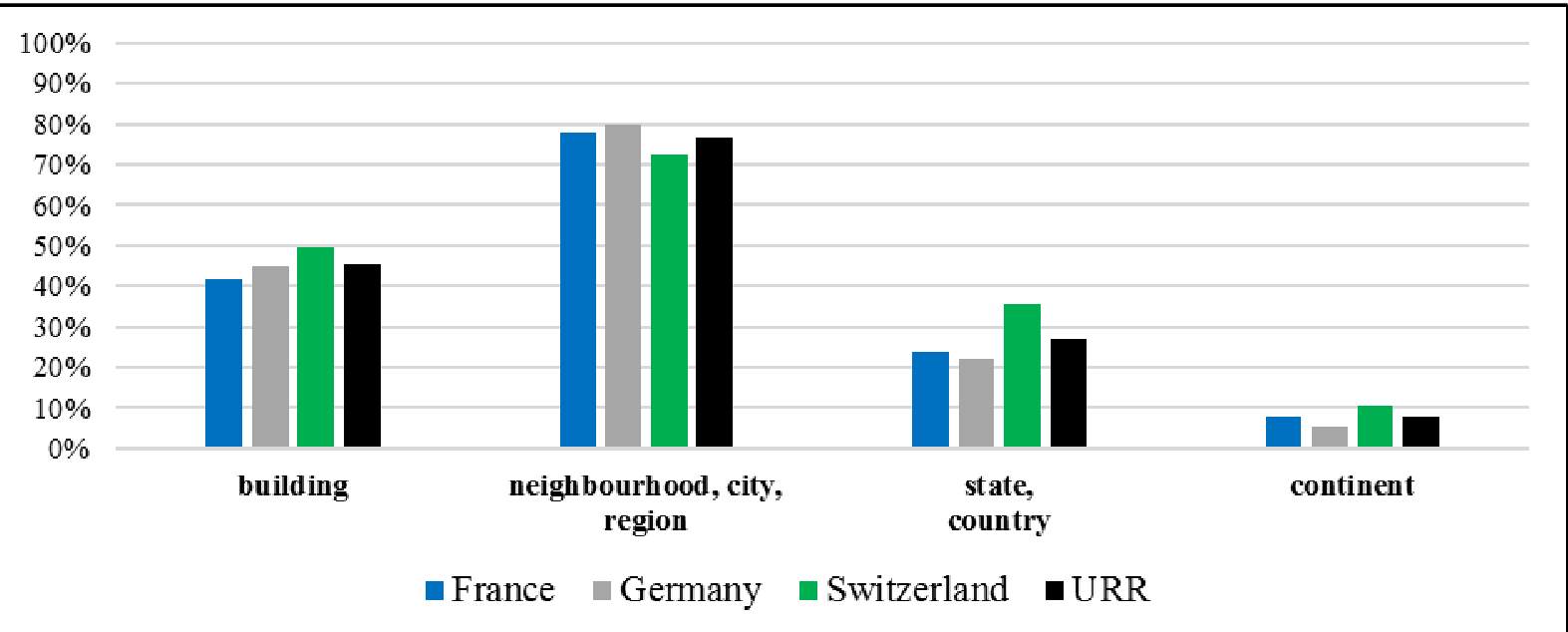

Figure 6 Frequency distribution of the answers to the question "On what level do you find energy autonomy most appropriate?"

Note: Sample sizes: $\mathrm{n}_{\text {Germany }}=495, \mathrm{n}_{\text {Switzerland }}=493, \mathrm{n}_{\text {France }}=501$ )

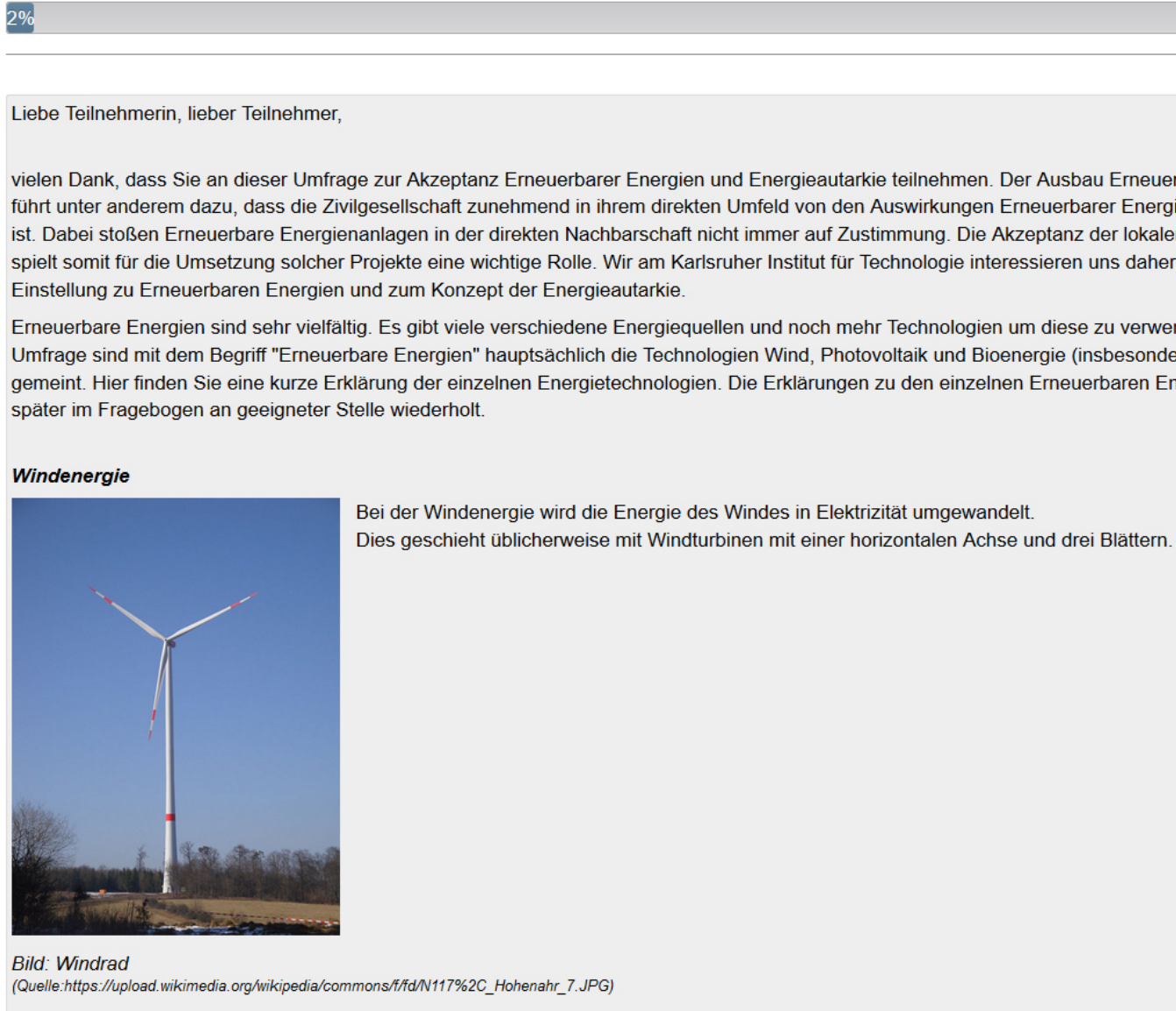


Wie negativ oder positiv bewerten Sie Photovoltaik-Kleinanlagen in Ihrer Nachbarschaft gesamthaft?

sehr negativ negativ

Als nächstes möchten wir gerne wissen, inwieweit Ihnen die Entfernung zwischen Ihrem Wohnhaus/ Ihrer Wohnung und der Photovoltaik-Kleinanlage wichtig ist.

Bitte kreuzen Sie die zutreffende Antwort an.

Für die Anlage(n) sollte ein Mindestabstand zu meinen Wohnhaus/ meiner Wohnung eingehalten werden.

Die Entfernung der Anlage(n) zu meinem Wohnhaus/ meiner Wohnung spielt keine Rolle.

Die Entfernung der Anlage(n) zu meinem Wohnhaus/ meiner Wohnung spielt keine Rolle aber die Anlage(n) sollte(n) nicht von meinem Wohnhaus/ meiner Wohnung aus sichtbar sein

Ich akzeptiere die Anlage(n) überhaupt nicht, egal in welcher Entfernung sie sich befindet.

Wie weit sollte eine Photovoltaik-Kleinanlage mindestens von Ihrem Wohnhaus/lhrer Wohnung entfernt sein, damit Sie diese akzeptieren würden?

Bitte klicken Sie auf den Balken, um den Abstand in Kilometern (km) zu wählen.

$<1 \mathrm{k}$

$\mathrm{m}$

$2 \mathrm{~km}$

$3 \mathrm{~km}$

$4 \mathrm{~km}$

$5 \mathrm{~km}$

$6 \mathrm{~km}$

$7 \mathrm{~km}$

$8 \mathrm{~km}$

$>9 \mathrm{k}$

Figure 7 Screenshots of the questionnaire 


\section{Tables}

\begin{tabular}{lccc}
\hline & \multicolumn{3}{c}{ Acceptance dimension } \\
\cline { 2 - 4 } Stakeholder & Socio-political & Community & Market \\
\hline Public & $\begin{array}{c}\text { Citizen, general } \\
\text { public }\end{array}$ & Resident & $\begin{array}{c}\text { Consumer, prosumer, } \\
\text { investor }\end{array}$ \\
\hline Government & $\begin{array}{c}\text { Regulator, policy } \\
\text { actor, legislative } \\
\text { authority }\end{array}$ & Local authority & $\begin{array}{c}\text { Regulator, policy actor, } \\
\text { taxing and subsidizing } \\
\text { authorities }\end{array}$ \\
\hline Companies & $\begin{array}{c}\text { Industry association, } \\
\text { lobbying group, focal } \\
\text { company }\end{array}$ & $\begin{array}{c}\text { Focal company, } \\
\text { investor, operator, } \\
\text { supplier }\end{array}$ & $\begin{array}{c}\text { Producer, distributor, } \\
\text { investor, network } \\
\text { operator, intra-firm } \\
\text { adopter }\end{array}$ \\
\hline Other & NGOs, media & $\begin{array}{c}\text { Local interest groups, } \\
\text { local clubs, local } \\
\text { media }\end{array}$ & $\begin{array}{c}\text { Consumer interest } \\
\text { groups }\end{array}$ \\
\hline
\end{tabular}

Table 1 Examples of stakeholder roles by social acceptance dimension (own depiction based on Fast (2013) and Upham et al. (2015))

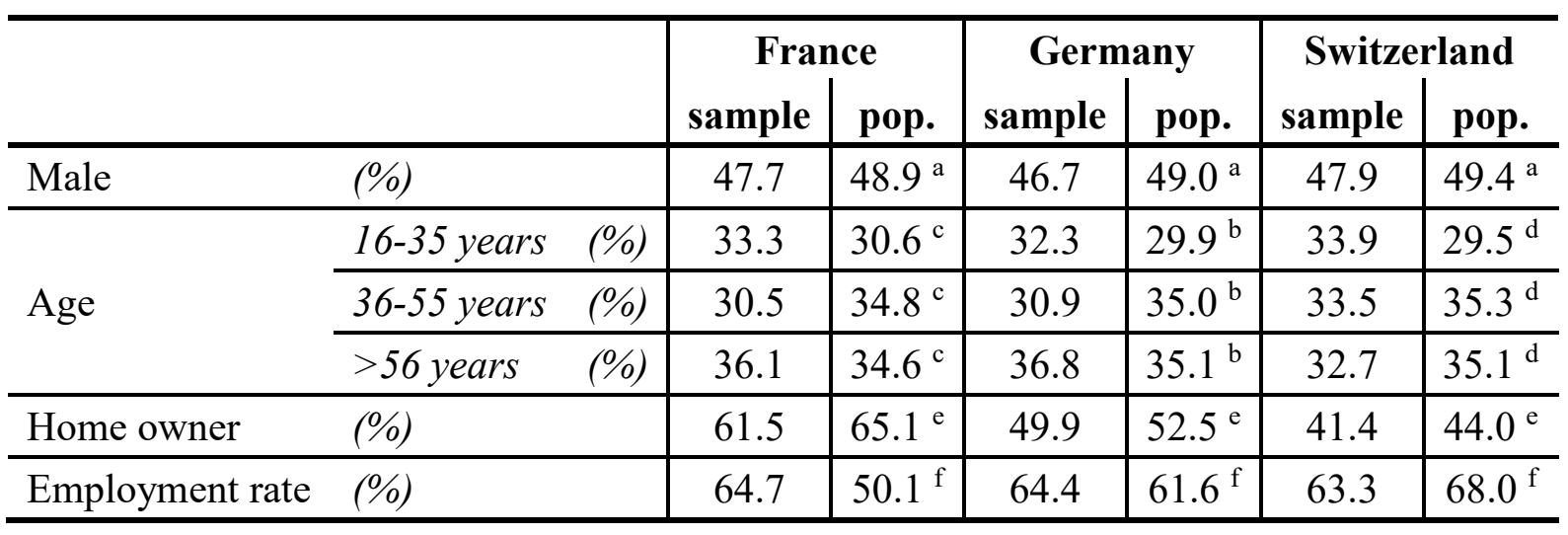

Table 2 Socio-demographic characteristics of the survey samples compared to population statistics

Notes:

${ }^{\text {a }}$ Based on Deutsch-Französische-Schweizerische Oberrheinkonferenz (2015), includes male population aged 15 or younger, data on URR level

${ }^{\mathrm{b}}$ Own calculation based on Statistisches Landesamt Baden-Württemberg (2011), data on regional level without Südpfalz

${ }^{c}$ Own calculation based on INSEE (2015), data on regional level, deviating classes: 15-34, 35-54, >55 years

${ }^{\mathrm{d}}$ Own calculation based on Bundesamt für Statistik (2014) data on canton level

${ }^{\mathrm{e}}$ Based on Eurostat (2014), data on country level

${ }^{\mathrm{f}}$ Based on Deutsch-Französische-Schweizerische Oberrheinkonferenz (2015), includes working population from the age of 15 , data on URR level 


\begin{tabular}{ll}
\hline Construct & Concept \\
\hline Advocacy of renewable energies & $\begin{array}{l}\text { Support of renewable energy technologies in general } \\
\text { and in the neighbourhood }\end{array}$ \\
\hline Engagement for renewable energies & $\begin{array}{l}\text { Engagement with regard to convincing others, } \\
\text { financial participation, and active support }\end{array}$ \\
\hline Advocacy of energy autonomy & $\begin{array}{l}\text { Support of approaches which lead to higher energy } \\
\text { autonomy in general and at the local level }\end{array}$ \\
\hline
\end{tabular}

Table 3 Constructs of the questionnaire

\begin{tabular}{lccccc}
\hline \multirow{2}{*}{ Construct } & \multicolumn{4}{c}{ Cronbach's $\boldsymbol{\alpha}$} & Number \\
\cline { 2 - 5 } & France & Germany & $\begin{array}{c}\text { Switzer- } \\
\text { land }\end{array}$ & URR & \\
\hline of items \\
Engacacy of renewable energies & 0.626 & 0.758 & 0.722 & 0.71 & 2 \\
Advocacy of energy autonomy & 0.664 & 0.847 & 0.81 & 0.78 & 3 \\
\hline
\end{tabular}

Table 4 Internal consistency of constructs for the overall sample (URR) and by sub-region 


\begin{tabular}{|c|c|c|c|c|c|c|c|c|c|c|c|c|c|c|c|c|c|c|c|c|c|c|}
\hline & & \multicolumn{3}{|c|}{$\begin{array}{l}\text { France } \\
(\mathrm{n}=501)\end{array}$} & \multicolumn{3}{|c|}{$\begin{array}{l}\text { Germany } \\
(\mathrm{n}=495)\end{array}$} & \multicolumn{3}{|c|}{$\begin{array}{c}\text { Switzerland } \\
(\mathrm{n}=493)\end{array}$} & \multicolumn{3}{|c|}{$\begin{array}{l}\text { One-way } \\
\text { ANOVA }\end{array}$} & \multicolumn{3}{|c|}{$\begin{array}{c}\text { Germany versus } \\
\text { France }\end{array}$} & \multicolumn{3}{|c|}{$\begin{array}{l}\text { Germany versus } \\
\text { Switzerland }\end{array}$} & \multicolumn{3}{|c|}{$\begin{array}{l}\text { France versus } \\
\text { Switzerland }\end{array}$} \\
\hline & & $n$ & $\mathrm{M}$ & $\mathrm{SD}$ & $\mathrm{n}$ & M & $\mathrm{SD}$ & $\mathrm{n}$ & M & $\mathrm{SD}$ & $\mathrm{df} 1^{\mathrm{a}}$ & $\mathrm{df} 2^{\mathrm{b}}$ & $\mathrm{p}$ & $\mathrm{df1} 1^{\mathrm{a}}$ & $\mathrm{df} 2^{\mathrm{b}}$ & $\mathrm{p}$ & $\mathrm{df1}^{\mathrm{a}}$ & $\mathrm{df} 2^{\mathrm{b}}$ & $\mathrm{p}$ & $\mathrm{df1}^{\mathrm{a}}$ & $\mathrm{df} 2^{\mathrm{b}}$ & $\mathrm{p}$ \\
\hline \multirow{3}{*}{$\begin{array}{l}\text { PV } \\
\text { small }\end{array}$} & Approval/Resistance & 473 & 3.98 & .835 & 487 & 4.40 & .784 & 467 & 4.30 & .816 & 2 & 1424 & .000 & 1 & 958 & .000 & 1 & 952 & .057 & 1 & 938 & .000 \\
\hline & of which support & 363 & 1.24 & .427 & 422 & 1.37 & .483 & 383 & 1.23 & .420 & 2 & 1165 & .000 & 1 & 783 & .000 & 1 & 803 & .000 & 1 & 744 & .687 \\
\hline & $\begin{array}{l}\text { of which } \\
\text { rejection }\end{array}$ & 21 & 1.71 & .463 & 10 & 1.80 & .422 & 8 & 1.75 & .463 & 2 & 36 & .885 & 1 & 29 & .624 & 1 & 16 & .814 & 1 & 27 & .854 \\
\hline \multirow{3}{*}{$\begin{array}{l}\text { PV } \\
\text { large }\end{array}$} & Approval/Resistance & 469 & 3.72 & .929 & 480 & 3.84 & .946 & 469 & 3.72 & .971 & 2 & 1415 & .086 & 1 & 947 & .060 & 1 & 947 & .052 & 1 & 936 & .918 \\
\hline & of which support & 305 & 1.33 & .470 & 315 & 1.38 & .486 & 274 & 1.26 & .437 & 2 & 891 & .005 & 1 & 618 & .168 & 1 & 587 & .001 & 1 & 577 & .056 \\
\hline & $\begin{array}{l}\text { of which } \\
\text { rejection }\end{array}$ & 48 & 1.44 & .501 & 38 & 1.79 & .413 & 46 & 1.67 & .474 & 2 & 129 & .002 & 1 & 84 & .001 & 1 & 82 & .242 & 1 & 92 & .021 \\
\hline \multirow{3}{*}{ Wind } & Approval/Resistance & 463 & 3.2 & 1.16 & 476 & 3.46 & 1.17 & 476 & 3.45 & 1.12 & 2 & 1412 & .001 & 1 & 937 & .001 & 1 & 950 & .910 & 1 & 937 & .001 \\
\hline & of which support & 209 & 1.28 & .449 & 245 & 1.40 & .492 & 227 & 1.26 & .437 & 2 & 678 & .001 & 1 & 452 & .005 & 1 & 470 & .001 & 1 & 435 & .604 \\
\hline & $\begin{array}{l}\text { of which } \\
\text { rejection }\end{array}$ & 129 & 1.48 & .502 & 106 & 1.67 & .473 & 85 & 1.6 & .493 & 2 & 317 & .012 & 1 & 233 & .003 & 1 & 189 & .321 & 1 & 212 & .088 \\
\hline \multirow{3}{*}{ Biogas } & Approval/Resistance & 420 & 3.29 & 1.02 & 459 & 3.17 & 1.14 & 463 & 3.39 & 1.04 & 2 & 1339 & .008 & 1 & 877 & .100 & 1 & 920 & .002 & 1 & 881 & .156 \\
\hline & of which support & 182 & 1.25 & .433 & 175 & 1.43 & .496 & 202 & 1.32 & .468 & 2 & 556 & .001 & 1 & 355 & .000 & 1 & 375 & .032 & 1 & 382 & .107 \\
\hline & $\begin{array}{l}\text { of which } \\
\text { rejection }\end{array}$ & 85 & 1.54 & .501 & 126 & 1.71 & .457 & 84 & 1.69 & .465 & 2 & 292 & .033 & 1 & 209 & .014 & 1 & 208 & .807 & 1 & 167 & .046 \\
\hline
\end{tabular}

Table 5 One-way ANOVA and post hoc analysis of differences in public acceptance of a RE plant in the neighbourhood between sub-regions by technology (significant results in bold)

Notes:

${ }^{a}$ degrees of freedom between groups

${ }^{b}$ degrees of freedom within groups 


\begin{tabular}{llccccccc}
\hline $\begin{array}{l}\text { Object of } \\
\text { acceptance }\end{array}$ & $\begin{array}{l}\text { Sub- } \\
\text { region }\end{array}$ & \multicolumn{3}{c}{ Socio-political } & \multicolumn{2}{c}{ Local } & \multirow{2}{*}{ p-value } & $\begin{array}{c}\text { Cohens } \\
\text { d }\end{array}$ \\
\cline { 2 - 6 } & & $\mathrm{n}$ & $\mathrm{M}$ & $\mathrm{SD}$ & $\mathrm{M}$ & $\mathrm{SD}$ & & \\
\hline \multirow{3}{*}{ REs } & France & 468 & 4.40 & .772 & 3.90 & .934 & $\mathbf{. 0 0 0}$ & 0.58 \\
& Germany & 485 & 4.63 & .765 & 4.43 & .842 & $\mathbf{. 0 0 0}$ & 0.25 \\
& Switzerland & 478 & 4.55 & .780 & 4.42 & .812 & $\mathbf{. 0 0 0}$ & 0.16 \\
\hline \multirow{3}{*}{ PV small } & France & 473 & 3.72 & .949 & 4.19 & .854 & $\mathbf{. 0 0 0}$ & 0.52 \\
& Germany & 483 & 4.53 & .735 & 4.63 & .750 & $\mathbf{. 0 0 0}$ & 0.14 \\
& Switzerland & 471 & 4.45 & .744 & 4.55 & .767 & $\mathbf{. 0 0 2}$ & 0.13 \\
\hline \multirow{3}{*}{ PV large } & France & 470 & 4.11 & .847 & 3.70 & 1.004 & $\mathbf{. 0 0 0}$ & 0.44 \\
& Germany & 478 & 4.47 & .779 & 3.97 & 1.020 & $\mathbf{. 0 0 0}$ & 0.55 \\
& Switzerland & 469 & 4.37 & .805 & 3.90 & 1.070 & $\mathbf{. 0 0 0}$ & 0.50 \\
\hline \multirow{3}{*}{ Wind } & France & 475 & 3.79 & 1.049 & 3.19 & 1.265 & $\mathbf{. 0 0 0}$ & 0.52 \\
& Germany & 484 & 4.34 & .917 & 3.56 & 1.277 & $\mathbf{. 0 0 0}$ & 0.78 \\
& Switzerland & 474 & 4.23 & .920 & 3.63 & 1.229 & $\mathbf{. 0 0 0}$ & 0.55 \\
\hline \multirow{3}{*}{ Biogas } & France & 428 & 3.76 & .936 & 3.34 & 1.053 & $\mathbf{. 0 0 0}$ & 0.42 \\
& Germany & 462 & 3.78 & 1.112 & 3.20 & 1.271 & $\mathbf{. 0 0 0}$ & 0.49 \\
& Switzerland & 458 & 4.00 & .917 & 3.52 & 1.103 & $\mathbf{. 0 0 0}$ & 0.47 \\
\hline
\end{tabular}

Table 6 T-test to compare public acceptance on the socio-political and community dimension by sub-region and technology (significant results in bold)

\begin{tabular}{llcccc}
\hline Response category & Sub-regions & \multicolumn{4}{c}{ Technology } \\
& & Small PV & Large PV & Wind & Biogas \\
\hline \multirow{2}{*}{$\begin{array}{l}\text { I do not accept the plant, } \\
\text { independent of the distance. }\end{array}$} & France & 2.8 & 4.4 & 14.4 & 12.6 \\
& Germany & 1.0 & 2.8 & 8.9 & 14.7 \\
& Switzerland & 1.6 & 5.1 & 8.1 & 9.3 \\
\hline The distance of the plant to & France & 42.7 & 25.0 & 15.2 & 15.4 \\
my home is not relevant for & Germany & 74.9 & 38.8 & 21.0 & 13.9 \\
me. & Switzerland & 70.2 & 41.4 & 24.7 & 18.7 \\
\hline The distance is not relevant & France & 16.4 & 22.8 & 17.2 & 17.6 \\
but the plant should not be & Germany & 7.9 & 23.6 & 16.6 & 21.0 \\
visible from my home. & Switzerland & 10.1 & 21.7 & 18.9 & 24.9 \\
\hline The plants should keep a & France & 38.1 & 47.9 & 53.3 & 54.5 \\
minimal distance to my & Germany & 16.2 & 34.7 & 53.5 & 50.3 \\
home. & Switzerland & 18.1 & 31.8 & 48.3 & 47.1 \\
\hline
\end{tabular}

Table 7 Role of proximity for the acceptance of different RE plants in percent (\%) of respondents by sub-region and technology 


\begin{tabular}{clcccc}
\hline & & France & Germany & $\begin{array}{c}\text { Switzer- } \\
\text { land } \\
(\mathrm{n}=501)\end{array}$ & $\begin{array}{c}\text { URR } \\
(\mathrm{n}=495)\end{array}$ \\
& & $\mathrm{n}=493)$ & $(\mathrm{n}=1489)$ \\
\hline \multirow{2}{*}{ Plant in direct vicinity } & total & 94 & 310 & 228 & 632 \\
& $\%$ & 18.8 & 62.6 & 46.2 & 42.4 \\
\hline Thereof PV & total & 78 & 279 & 189 & 546 \\
small & $\%$ & 83 & 90 & 82.9 & 86.4 \\
\hline \multirow{2}{*}{ Thereof PV large } & total & 23 & 52 & 42 & 117 \\
& $\%$ & 24.5 & 16.8 & 18.4 & 18.5 \\
\hline \multirow{2}{*}{ Thereof wind } & total & 14 & 102 & 23 & 139 \\
& $\%$ & 14.9 & 32.9 & 10.1 & 22 \\
\hline \multirow{2}{*}{ Thereof biogas } & total & 7 & 30 & 38 & 75 \\
& $\%$ & 7.4 & 9.7 & 16.7 & 11.9 \\
\hline
\end{tabular}

Table 8 Share of respondents with RE plant in direct vicinity by sub-region and technology 


\begin{tabular}{|c|c|c|c|c|c|c|c|c|}
\hline \multirow[t]{2}{*}{$\begin{array}{l}\text { Object of } \\
\text { acceptance }\end{array}$} & \multirow[t]{2}{*}{ Sub-region } & \multicolumn{3}{|c|}{$\begin{array}{l}\text { With plant } \\
\text { in vicinity }\end{array}$} & \multicolumn{3}{|c|}{$\begin{array}{l}\text { Without plant } \\
\text { in vicinity }\end{array}$} & \multirow[t]{2}{*}{ p-value } \\
\hline & & $\mathrm{n}$ & M & $\mathrm{SD}$ & $\mathrm{n}$ & M & $\mathrm{SD}$ & \\
\hline \multirow{4}{*}{ REs } & France & 93 & 4.03 & .902 & 376 & 3.87 & .939 & .133 \\
\hline & Germany & 307 & 4.58 & .683 & 178 & 4.18 & 1.02 & .000 \\
\hline & Switzerland & 227 & 4.48 & .772 & 252 & 4.37 & .844 & .149 \\
\hline & URR & 627 & 4.46 & .773 & 806 & 4.10 & .953 & .000 \\
\hline \multirow{4}{*}{ Small PV plants } & France & 76 & 4.42 & .753 & 410 & 4.14 & .877 & .008 \\
\hline & Germany & 278 & 4.80 & .524 & 210 & 4.41 & .940 & .000 \\
\hline & Switzerland & 187 & 4.63 & .732 & 289 & 4.47 & .799 & .031 \\
\hline & URR & 541 & 4.69 & .650 & 909 & 4.31 & .881 & .000 \\
\hline \multirow{4}{*}{ Large PV plants } & France & 23 & 4.00 & .853 & 464 & 3.66 & 1.02 & .117 \\
\hline & Germany & 51 & 4.35 & .890 & 434 & 3.91 & 1.05 & .004 \\
\hline & Switzerland & 42 & 4.38 & .936 & 432 & 3.84 & 1.08 & .002 \\
\hline & URR & 116 & 4.29 & .904 & 1330 & 3.80 & 1.05 & .000 \\
\hline \multirow{4}{*}{ Wind energy plants } & France & 14 & 3.71 & 1.27 & 474 & 3.15 & 1.27 & .099 \\
\hline & Germany & 101 & 4.00 & 1.13 & 385 & 3.44 & 1.29 & .000 \\
\hline & Switzerland & 23 & 3.96 & 1.22 & 455 & 3.62 & 1.23 & .202 \\
\hline & URR & 138 & 3.96 & 1.16 & 1314 & 3.40 & 1.27 & .000 \\
\hline \multirow{4}{*}{ Biogas plants } & France & 7 & 3.86 & .690 & 450 & 3.30 & 1.06 & .168 \\
\hline & Germany & 30 & 3.50 & 1.33 & 437 & 3.19 & 1.26 & .189 \\
\hline & Switzerland & 38 & 3.61 & 1.15 & 433 & 3.49 & 1.11 & .546 \\
\hline & URR & 75 & 3.59 & 1.19 & 1320 & 3.33 & 1.15 & .056 \\
\hline
\end{tabular}

Table 9 T-test to compare local acceptance between respondents with and without RE plants in direct vicinity (significant results in bold) 


\begin{tabular}{|c|c|c|c|c|c|c|c|c|}
\hline & \multicolumn{2}{|c|}{ France } & \multicolumn{2}{|c|}{ Germany } & \multicolumn{2}{|c|}{$\begin{array}{l}\text { Switzer- } \\
\text { land }\end{array}$} & \multicolumn{2}{|c|}{ URR } \\
\hline & $\mathrm{r}$ & $\mathrm{n}$ & $\mathrm{r}$ & $\mathrm{n}$ & $r$ & $\mathrm{n}$ & $\mathrm{r}$ & $\mathrm{n}$ \\
\hline $\begin{array}{l}\text { 'advocacy of energy autonomy' and } \\
\text { 'advocacy of renewable energies' }\end{array}$ & $* * .466$ & 467 & $* * .518$ & 467 & $* * .466$ & 471 & $* * .480$ & 1,405 \\
\hline $\begin{array}{l}\text { 'advocacy of energy autonomy' and } \\
\text { 'engagement for renewable energies' }\end{array}$ & .089 & 469 & $* * .183$ & 468 & .061 & 471 & $* .106$ & 1,408 \\
\hline $\begin{array}{l}\text { 'advocacy of renewable energies' and } \\
\text { 'engagement for renewable energies' }\end{array}$ & $* * .123$ & 494 & *.109 & 493 & .065 & 487 & $* * .080$ & 1,474 \\
\hline
\end{tabular}

Table 10 Pearson's correlation coefficient (r) between the constructs 'advocacy of energy autonomy', 'advocacy of renewable energies', and 'engagement for renewable energies' (significant results in bold)

Note: $* * \mathrm{p}<.01, * \mathrm{p}<.05$.

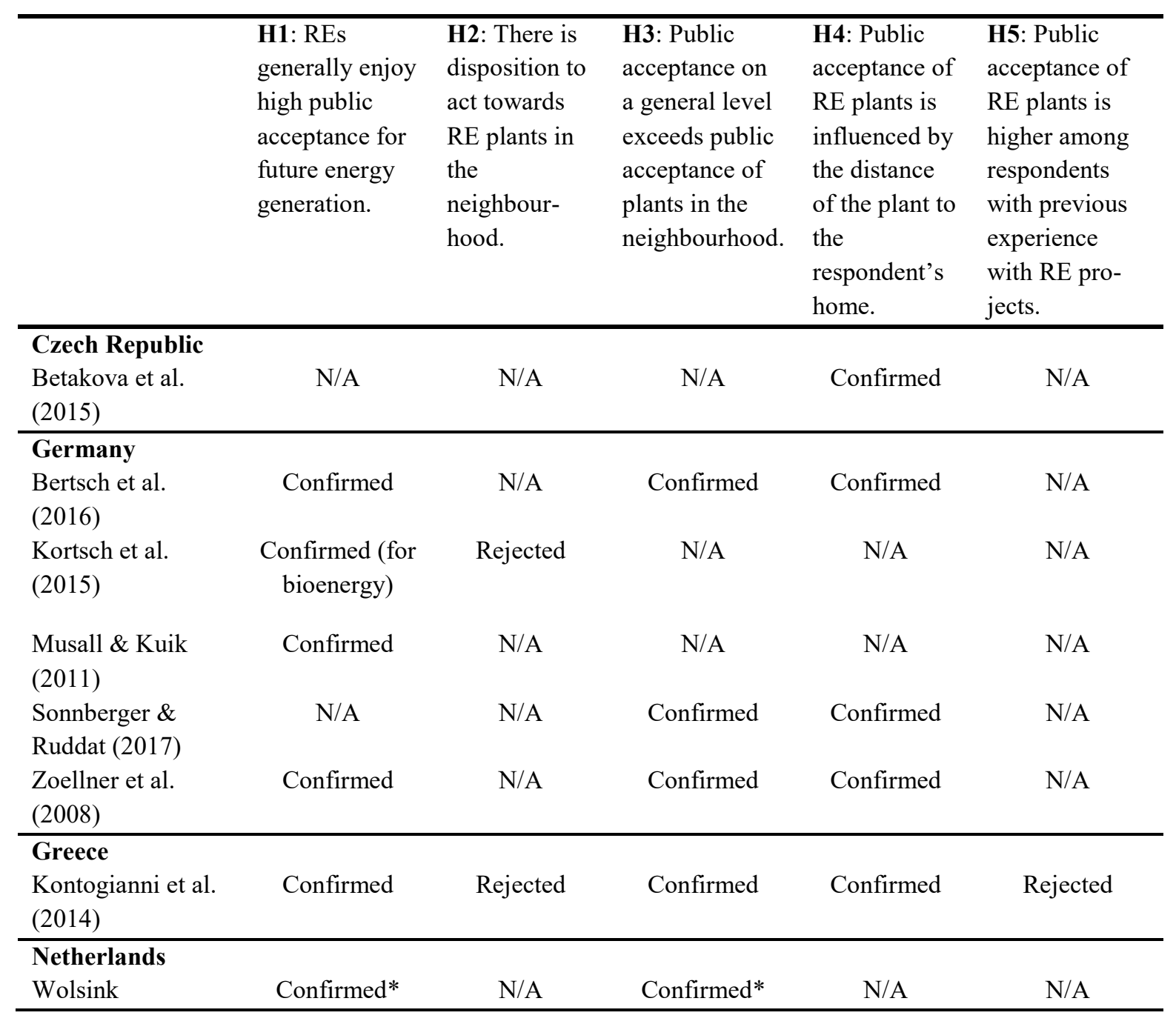


(2000)

\begin{tabular}{|c|c|c|c|c|c|}
\hline \multicolumn{6}{|l|}{ Switzerland } \\
\hline $\begin{array}{l}\text { Soland et. al. } \\
\text { (2013) }\end{array}$ & N/A & N/A & N/A & N/A & Confirmed* \\
\hline $\begin{array}{l}\text { Sütterin \& Siegrist } \\
\text { (2017) }\end{array}$ & Confirmed & $\mathrm{N} / \mathrm{A}$ & Confirmed & $\mathrm{N} / \mathrm{A}$ & $\mathrm{N} / \mathrm{A}$ \\
\hline \multicolumn{6}{|l|}{ United Kingdom } \\
\hline Upreti (2004) & $\begin{array}{l}\text { Rejected (for } \\
\text { bioenergy) }\end{array}$ & Confirmed & Confirmed & N/A & N/A \\
\hline $\begin{array}{l}\text { Upreti \& van der } \\
\text { Horst (2004) }\end{array}$ & $\begin{array}{l}\text { Rejected* (for } \\
\text { bioenergy) }\end{array}$ & $\mathrm{N} / \mathrm{A}$ & Confirmed & N/A & N/A \\
\hline $\begin{array}{l}\text { Upham \& } \\
\text { Shackley (2006) }\end{array}$ & Confirmed* & N/A & Confirmed & N/A & N/A \\
\hline $\begin{array}{l}\text { Upham \& } \\
\text { Shackley (2007) }\end{array}$ & $\begin{array}{l}\text { Confirmed } \\
\text { (except for } \\
\text { bioenergy) }\end{array}$ & $\mathrm{N} / \mathrm{A}$ & Confirmed & N/A & N/A \\
\hline Upham (2009) & Confirmed* & $\mathrm{N} / \mathrm{A}$ & Confirmed & N/A & N/A \\
\hline \multicolumn{6}{|l|}{ USA } \\
\hline $\begin{array}{l}\text { France \& Germany } \\
\text { Jobert et al. (2007) }\end{array}$ & N/A & N/A & N/A & $\begin{array}{l}\text { Confirmed } \\
\text { (regarding } \\
\text { visibility) }\end{array}$ & N/A \\
\hline $\begin{array}{l}\text { Ireland \& Scotland } \\
\text { Warren et al. } \\
(2005)\end{array}$ & Confirmed & N/A & Confirmed & $\begin{array}{l}\text { Confirmed } \\
\text { for Scotland, } \\
\text { rejected for } \\
\text { Ireland }\end{array}$ & $\begin{array}{l}\text { Confirmed for } \\
\text { Ireland, } \\
\text { N/A for } \\
\text { Ireland }\end{array}$ \\
\hline \multicolumn{6}{|c|}{ Norway, Sweden \& UK } \\
\hline Aas et al. (2014) & $\begin{array}{l}\text { Confirmed (for } \\
\text { high voltage } \\
\text { power lines) }\end{array}$ & $\mathrm{N} / \mathrm{A}$ & Confirmed & N/A & N/A \\
\hline \multicolumn{6}{|c|}{ France, Germany \& Switzerland } \\
\hline $\begin{array}{l}\text { Schumacher \& } \\
\text { Schultmann } \\
(2017)\end{array}$ & N/A & Confirmed & N/A & Confirmed & N/A \\
\hline This study & Confirmed & Confirmed & Confirmed & Confirmed & Confirmed \\
\hline
\end{tabular}

Table 11 Comparison of findings with related work by country

Notes:

* Not empirically assessed by own data.

N/A: The hypothesis has not been addressed. 
Public Acceptance of Renewable Energies and Energy Autonomy in Different Energy Policy Contexts:

A Comparative Study in the French, German and Swiss Upper Rhine Region

\begin{tabular}{|c|c|c|c|}
\hline Construct & Item & Source & Item \\
\hline Single item & General appraisal of REs & Based on Wüste (2013) & $\begin{array}{l}\text { Small-scale PV/large-scale PV/wind energy/ biogas plants are a suitable form of energy } \\
\text { generation. }^{\text {a }}\end{array}$ \\
\hline \multirow[t]{2}{*}{$\begin{array}{l}\text { Advocacy of renewable } \\
\text { energies }\end{array}$} & Future energy generation & $\begin{array}{l}\text { Based on Schweizer- } \\
\text { Ries et al. } \\
(2010), \text { Rau \& Zoellner } \\
(2008)\end{array}$ & $\begin{array}{l}\text { Renewable energies (e.g. solar, wind, bioenergy) should play an important role in future } \\
\text { energy generation. }^{\text {a }}\end{array}$ \\
\hline & Local support & $\begin{array}{l}\text { Schweizer-Ries et al. } \\
(2010)\end{array}$ & All in all, I support renewable energy facilities in my neighbourhood. ${ }^{a}$ \\
\hline Single item & $\begin{array}{l}\text { Acceptance of local } \\
\text { plants }\end{array}$ & $\begin{array}{l}\text { Based on Schweizer- } \\
\text { Ries et al. (2010) }\end{array}$ & I support small-scale PV/large-scale PV/wind energy/ biogas plants in my neighbourhood. ${ }^{\text {a }}$ \\
\hline Single item & Appraisal of local plants & $\begin{array}{l}\text { Newly developed, } \\
\text { based on Schweizer-Ries } \\
(2008)\end{array}$ & $\begin{array}{l}\text { How do you rate small-scale PV/large-scale PV/wind energy/ biogas plants in your } \\
\text { neighbourhood? }{ }^{\mathrm{b}}\end{array}$ \\
\hline Single item & $\begin{array}{l}\text { Active support of local } \\
\text { plants }\end{array}$ & $\begin{array}{l}\text { Newly developed, } \\
\text { based on Schweizer-Ries } \\
(2008)\end{array}$ & $\begin{array}{l}\text { Are you in principle prepared to actively support a small-scale } P V / \text { large-scale } P V / \text { wind } \\
\text { energy/ biogas plant in your neighbourhood? }{ }^{c}\end{array}$ \\
\hline Single item & $\begin{array}{l}\text { Active resistance } \\
\text { towards local plants }\end{array}$ & $\begin{array}{l}\text { Newly developed, } \\
\text { based on Schweizer-Ries } \\
(2008)\end{array}$ & $\begin{array}{l}\text { Are you in principle prepared to actively oppose a small-scale PV/large-scale } P V / \text { wind } \\
\text { energy/ biogas plant in your neighbourhood? }{ }^{\mathrm{c}}\end{array}$ \\
\hline Single item & Relevance of distance & Newly developed & $\begin{array}{l}\text { To what extent is the distance between your house/ apartment and a small-scale PV/ large- } \\
\text { scale } P V \text { /wind energy/biogas plant important to you? } \mathrm{d}\end{array}$ \\
\hline Single item & $\begin{array}{l}\text { Desired distance to local } \\
\text { plant }\end{array}$ & $\begin{array}{l}\text { Based on Griesen } \\
(2010), \\
\text { Bertsch et al. (2016) }\end{array}$ & $\begin{array}{l}\text { What should be the minimum distance of a small-scale PV/large-scale PV/wind energy/ } \\
\text { biogas plant to your home for you to accept the plant? }{ }^{\mathrm{e}}\end{array}$ \\
\hline Single item & $\begin{array}{l}\text { Familiarity with energy } \\
\text { autonomy }\end{array}$ & Newly developed & Do you know the term "energy autonomy"?c \\
\hline Single item & $\begin{array}{l}\text { Knowledge of energy } \\
\text { autonomy }\end{array}$ & Newly developed & How do you rate your general knowledge of renewable energies? ${ }^{f}$ \\
\hline \multirow{3}{*}{$\begin{array}{l}\text { Engagement for } \\
\text { renewable energies }\end{array}$} & Convince others & Rau \& Zoellner (2008) & I try to convince my friends during conversations about the benefits of renewable energies. ${ }^{\mathrm{g}}$ \\
\hline & Financial participation & Rau \& Zoellner (2008) & I am interested in financially participating in a renewable energy plant. ${ }^{\mathrm{h}}$ \\
\hline & $\begin{array}{l}\text { General active support of } \\
\text { REs }\end{array}$ & $\begin{array}{l}\text { Based on Schweizer- } \\
\text { Ries et al. (2010) }\end{array}$ & $\begin{array}{l}\text { Are you in principle willing to actively support a renewable energy plant in your } \\
\text { neighbourhood? (E.g., through membership in a citizens' initiative or in a cooperative) }{ }^{\mathrm{h}}\end{array}$ \\
\hline Single item & Community energy & Newly developed & Are you already supporting local renewable energy projects? ${ }^{\mathrm{i}}$ \\
\hline \multirow{3}{*}{$\begin{array}{l}\text { Advocacy of energy } \\
\text { autonomy }\end{array}$} & General support & Newly developed & All in all, I think that approaches leading to higher local energy autonomy make sense. ${ }^{a}$ \\
\hline & Local support & Newly developed & I support approaches which lead to higher energy autonomy in my neighbourhood. ${ }^{a}$ \\
\hline & Appraisal & Newly developed & How do you rate energy autonomy in your neighbourhood? ${ }^{\mathrm{b}}$ \\
\hline
\end{tabular}


Table 12 Items and construct measures (translated from German)

Notes:

${ }^{\text {a }}$ Five-point Likert scale with $1=$ "entirely incorrect" and $5=$ "completely correct" as anchors and $90=$ "don't know"

${ }^{\mathrm{b}}$ Five- point Likert scale with 1 = "very negative" and $5=$ "very positive" as anchors and 90 = "don't know"

c 1 = "Yes", 2 = "No"

d 1 = "I do not accept the plant, independent of the distance.", 2 = "The distance of the plant to my home is not relevant for me.", $3=$ "The distance is not relevant but the plant should not be visible from my home.", 4 = "The plants should keep a minimal distance to my home."

e $<1$ kilometre $(\mathrm{km}), 1 \mathrm{~km}, 2 \mathrm{~km}, 3 \mathrm{~km}, 4 \mathrm{~km}, 5 \mathrm{~km}, 6 \mathrm{~km}, 7 \mathrm{~km}, 8 \mathrm{~km},>9 \mathrm{~km}$

${ }^{\mathrm{f}}$ Five-point Likert scale with $1=$ "very bad" and 5 = "very good"

g Five-point Likert scale with 1 = "never" and 5 = "always"

h 1 = "Yes", 2 = "No", 3 = "I am undecided"

i 1 = "No, I am not supporting any local renewable energy project.", 2 = "Yes, I am running my own plant.", $3=$ "Yes, I am financially involved in a renewable energy plant.", 4 = "Yes, I am a member of an energy cooperative.", 5 = "Yes, I am engaged in another form than the above (please briefly describe your commitment)." 